\title{
Internal Rotation in Propionic Acid: Near-Infrared-Induced Isomerization in Solid Argon
}

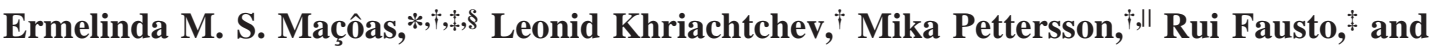 \\ Markku Räsänen ${ }^{\dagger}$ \\ Laboratory of Physical Chemistry, University of Helsinki, P.O. Box 55, FIN-00014 Helsinki, Finland, and \\ Department of Chemistry (CQC), University of Coimbra, P-3004-535 Coimbra, Portugal
}

Received: December 30, 2004; In Final Form: March 9, 2005

\begin{abstract}
The conformational system of propionic acid $\left(\mathrm{CH}_{3} \mathrm{CH}_{2} \mathrm{COOH}\right)$ is studied in solid argon. It is predicted by the ab initio calculations that this molecule has four stable conformers. These four structures are denoted $\mathrm{T}_{\mathrm{t}}, \mathrm{T}_{\mathrm{g}}{ }^{ \pm}$, $\mathrm{C}_{\mathrm{t}}$, and $\mathrm{C}_{\mathrm{g}}{ }^{ \pm}$, and they differ by the arrangement around the $\mathrm{C}-\mathrm{O}$ and $\mathrm{C}_{\alpha}-\mathrm{C}$ bonds. The ground-state $\mathrm{T}_{\mathrm{t}}$ conformer is the only form present at $8 \mathrm{~K}$ after deposition of an argon matrix containing propionic acid. For the $\mathrm{CH}_{3} \mathrm{CH}_{2} \mathrm{COOH}$ and $\mathrm{CH}_{3} \mathrm{CH}_{2} \mathrm{COOD}$ isotopologues, narrow-band excitation of the first hydroxyl stretching overtone of the conformational ground state promotes the $\mathrm{C}_{\alpha}-\mathrm{C}$ and $\mathrm{C}-\mathrm{O}$ internal rotations producing the $\mathrm{T}_{\mathrm{g}}{ }^{ \pm}$and $\mathrm{C}_{\mathrm{t}}$ conformers, respectively. A subsequent vibrational excitation of the produced $\mathrm{T}_{\mathrm{g}}{ }^{ \pm}$form induces its conversion to the $\mathrm{C}_{\mathrm{g}}{ }^{ \pm}$conformer by rotation around the $\mathrm{C}-\mathrm{O}$ bond. In the dark, all of the produced conformers decay to the conformational ground state at different rates. The decay kinetics and its temperature dependence allow the identification of the conformers by IR absorption spectroscopy, which is supported by ab initio calculations of their vibrational spectra. For the $\mathrm{CH}_{3} \mathrm{CH}_{2} \mathrm{COOD}$ isotopologue, the excitation of molecules isolated in different matrix sites results in site-dependent photoisomerization rates for the $\mathrm{C}_{\alpha}-\mathrm{C}$ and $\mathrm{C}-\mathrm{O}$ internal rotations, which also confirm the identification of the photoproducts.
\end{abstract}

\section{Introduction}

In a recent series of papers, we studied the IR-induced rotational isomerization of formic and acetic acids isolated in low-temperature inert matrixes. ${ }^{1-7}$ These studies have been mainly motivated by our interest in the conformational dynamics of the carboxylic group as a way to understand the process of intramolecular vibrational energy relaxation, which plays an important role in molecular reactivity. Interestingly, the photolysis of formic acid was shown to be conformationally dependent, being acknowledged as one of the first clear cases of optical control of chemical reactivity. ${ }^{4,8}$ The study of the conformational properties of simple carboxylic acids can improve our knowledge of more complex molecular systems with biological interest, where the conformation of this functional group plays an important role in determining their biological activity. ${ }^{9-11}$ Furthermore, an understanding of the conformational properties of small molecules and their response to photochemical stimuli is essential to the evaluation of the potential use of more complex molecules with biconformational structure as molecular switches controlled by light. ${ }^{12,13}$

Compared to acetic acid, propionic acid (propanoic acid, $\mathrm{CH}_{3-}$ $\mathrm{CH}_{2} \mathrm{COOH}$ ) has one additional internal rotational degree of freedom. Besides the methyl and hydroxyl rotations occurring in acetic acid, the internal rotation around the $\mathrm{C}_{\alpha}-\mathrm{C}$ bond should be taken into account in the case of propionic acid. Experimentally, only one conformer of monomeric propionic acid has

* To whom correspondence should be addressed. E-mail: emacoas@ qui.uc.pt.

University of Helsinki.

$\doteqdot$ University of Coimbra.

$\S$ Present address: Department of Chemistry (CQC), University of Coimbra, P-3004-535 Coimbra, Portugal.

"Present address: Department of Chemistry, NanoScience Center, University of Jyväskyla, P.O. Box 35, FIN-40014, Finland. been unequivocally characterized. ${ }^{14-16}$ Both gas-phase electron diffraction and microwave spectroscopy studies have shown that this conformer exhibits a planar heavy-atom backbone, with a staggered arrangement around the $\mathrm{C}_{\beta}-\mathrm{C}_{\alpha}$ bond and trans arrangements around the $\mathrm{C}_{\alpha}-\mathrm{C}$ and $\mathrm{C}-\mathrm{O}$ bonds $(\mathrm{C}-\mathrm{C}-\mathrm{C}-\mathrm{O}$ and $\mathrm{C}-\mathrm{C}-\mathrm{O}-\mathrm{H}$ dihedral angles of $\left.180^{\circ}\right) .{ }^{14-16}$ Moreover, the electron diffraction results suggested that, in addition to the identified conformer, structures bearing a nonplanar $\mathrm{C}-\mathrm{C}-\mathrm{C}-\mathrm{O}$ skeleton should also contribute to the gas-phase equilibrium conformational distribution with an estimated population of ca. $40 \%(T=488 \mathrm{~K}) \cdot{ }^{14}$

The earlier computational studies on the conformational isomerism in propionic acid, undertaken at the ab initio HartreeFock (HF) level of theory with the relatively modest $6-31 \mathrm{G}^{*}$ basis set ${ }^{17}$ and using the molecular mechanics (MM) approach, ${ }^{18}$ predicted two stable arrangements with respect to the $\mathrm{C}_{\alpha}-\mathrm{C}$ bond, the trans and gauche $(\mathrm{C}-\mathrm{C}-\mathrm{C}-\mathrm{O}$ dihedral angle of ca. $\left.\pm 60^{\circ}\right)$ arrangements. The doubly degenerate gauche arrangement has been estimated by MM to be $490 \mathrm{~cm}^{-1}$ higher in energy than the trans arrangement, ${ }^{18}$ whereas the $\mathrm{HF} / 6-31 \mathrm{G}^{*}$ calculations predicted a slightly smaller gauche-trans energy difference $\left(\sim 340 \mathrm{~cm}^{-1}\right) .{ }^{17}$ The trans-gauche barrier estimated by the HF/ 6-31G* calculations was $\sim 420 \mathrm{~cm}^{-1},{ }^{17}$ which was in good agreement with a more recent value of $490 \mathrm{~cm}^{-1}$ obtained using the density functional theory (DFT) method with the B3LYP functional and the $6-311++\mathrm{G}(2 \mathrm{~d}, 2 \mathrm{p})$ basis set. ${ }^{19}$ The relative stability of these two $\mathrm{C}_{\alpha}-\mathrm{C}$ arrangements can be compared with other carbonyl compounds structurally related to propionic acid, such as propionyl fluoride and propionyl chloride $\left(\mathrm{CH}_{3} \mathrm{CH}_{2-}\right.$ $\mathrm{COX}$, with $\mathrm{X}=\mathrm{F}$ and $\mathrm{Cl}$ ), which have been studied previously. ${ }^{20,21}$ These molecules were shown to be stable in the trans and gauche conformations with respect to the $\mathrm{C}_{\alpha}-\mathrm{C}$ bond $(\mathrm{C}-$ $\mathrm{C}-\mathrm{C}-\mathrm{X}$ dihedrals of 180 and ca. $\pm 60^{\circ}$, respectively). ${ }^{20,21}$ In solutions of liquid rare gases, the energy differences between 
the trans and the gauche conformers and the trans $\rightarrow$ gauche isomerization barrier were found to be 329 and $680 \mathrm{~cm}^{-1}$ in propionyl fluoride and 505 and $820 \mathrm{~cm}^{-1}$ in propionyl chloride, respectively. ${ }^{20,21}$ For chloroacetic acid $\left(\mathrm{CH}_{2} \mathrm{ClCOOH}\right)$, the gauche arrangement around the $\mathrm{C}_{\alpha}-\mathrm{C}$ bond was estimated to be $120-400 \mathrm{~cm}^{-1}$ higher in energy than the trans form, with a trans $\rightarrow$ gauche isomerization barrier of ca. $500 \mathrm{~cm}^{-1}$ for the monomer isolated in rare-gas matrixes..$^{22-24}$

Computationally, in addition to the two stable arrangements around the $\mathrm{C}_{\alpha}-\mathrm{C}$ bond, propionic acid has two stable conformations differing in the arrangement around the $\mathrm{C}-\mathrm{O}$ bond, corresponding to the planar trans and cis configurations characterized by $\mathrm{C}-\mathrm{C}-\mathrm{O}-\mathrm{H}$ dihedrals of 180 and $0^{\circ}$, respectively. ${ }^{18,19}$ Similarly to the situation in formic and acetic acids, ${ }^{1,5}$ in propionic acid the trans arrangement of the carboxylic group is the lowest-energy configuration. According to MM and DFT/ B3LYP calculations, the energy difference between the two configurations is ca. $1700-2100 \mathrm{~cm}^{-1} \cdot{ }^{18,19}$ The trans to cis barrier associated with internal rotation around the $\mathrm{C}-\mathrm{O}$ bond estimated by the same methods is $4300-4600 \mathrm{~cm}^{-1} .{ }^{19}$ These results are in good agreement with the data for formic and acetic acids (energy difference of $\sim 1400-1800 \mathrm{~cm}^{-1}$ and a trans to cis barrier of $\left.\sim 3900-4400 \mathrm{~cm}^{-1}\right) .{ }^{25-28}$ For the matrix-isolated monomers of formic and acetic acids, the cis conformer is shortlived, even at $8 \mathrm{~K}$, because of its conversion to the trans conformer by tunneling with a rate of $\sim 10^{-2}-10^{-3} \mathrm{~s}^{-1,3,7}$ which complicates the experimental characterization of the cis conformer of these molecules. A similar phenomenon can also be expected for propionic acid.

In the present study, the rotational isomerization of monomeric propionic acid isolated in solid argon was investigated. The ground-state potential energy surface (PES) and the vibrational spectra of its different conformers were calculated at the MP2/6-311G++(2d,2p) level of theory. The computational results support the analysis of the experimental data obtained using the low-temperature matrix-isolation technique combined with narrow-band pumping of individual vibrational transitions.

\section{Experimental and Computational Details}

The gaseous samples were prepared by mixing propionic acid (>99\%), degassed by several freeze-pump-thaw cycles, with high-purity argon $(99.9999 \%)$, in a 1:1000 or 1:500 ratio. The $\mathrm{CH}_{3} \mathrm{CH}_{2} \mathrm{COOD}$ species was obtained from the fully hydrogenated isotopologue by H/D exchange on both the inner surface of the sample container and the deposition line saturated with $\mathrm{D}_{2} \mathrm{O}$. The $\mathrm{OH}$ and $\mathrm{OD}$ isotopologues of propionic acid are referred to as $\mathrm{PA}-\mathrm{OH}$ and PA-OD. The gaseous mixtures, initially kept at room temperature, were deposited onto a CsI substrate at $15 \mathrm{~K}$ in a closed-cycle helium cryostat (APD, DE 202A) and subsequently cooled to $8 \mathrm{~K}$. The IR absorption spectra $\left(7900-400 \mathrm{~cm}^{-1}\right)$ were measured with a Nicolet SX60 FTIR spectrometer. A liquid-nitrogen-cooled MCT detector and a $\mathrm{Ge} / \mathrm{KBr}$ beam splitter were used to record the mid-IR absorption spectra, with spectral resolutions of 0.25 to $1.0 \mathrm{~cm}^{-1}$. A liquid-nitrogen-cooled InSb detector and a quartz beam splitter were used to record the near-IR (NIR) absorption spectra, with a spectral resolution of $0.5 \mathrm{~cm}^{-1}$. Typically, 100 to 500 interferograms were added.

Tunable pulsed IR radiation provided by an optical parametric oscillator (Continuum, OPO Sunlite with IR extension) was used to excite the first overtone of the hydroxyl stretching mode $(2 \nu \mathrm{OH}$ or $2 \nu \mathrm{OD})$ of various conformers of propionic acid. The pulse duration was ca. $5 \mathrm{~ns}$, the spectral line width was $\sim 0.1$

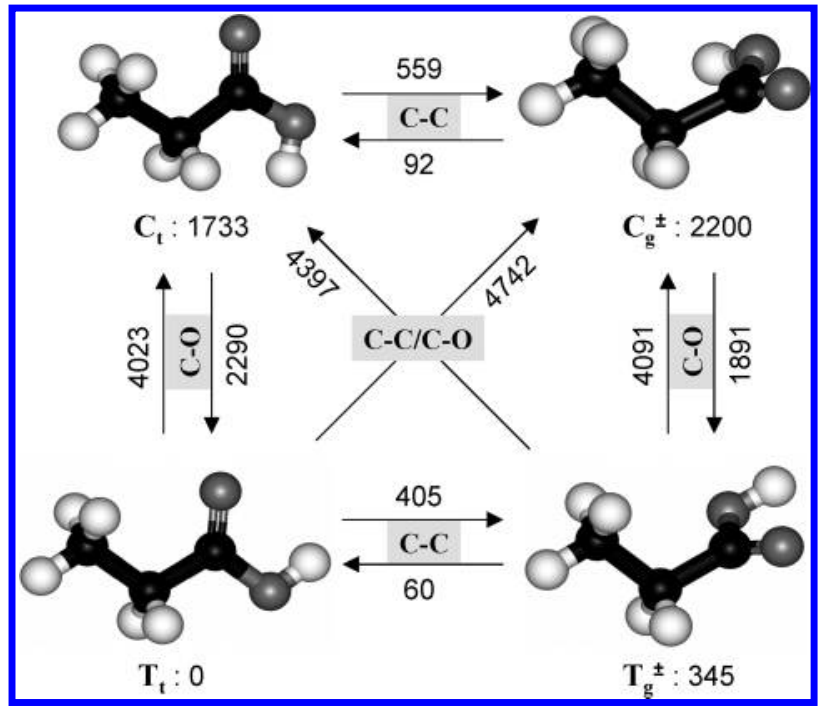

Figure 1. Conformers of propionic acid. Shown are the ab initio [MP2/ 6-311++G $(2 \mathrm{~d}, 2 \mathrm{p})]$ relative conformational energies and energy barriers for the internal rotation around the $\mathrm{C}_{\alpha}-\mathrm{C}$ and $\mathrm{C}-\mathrm{O}$ bonds $\left(\right.$ in $\mathrm{cm}^{-1}$ ).

$\mathrm{cm}^{-1}$, and the repetition rate was $10 \mathrm{~Hz}$. The pulse energy of the OPO in the $7000-5000 \mathrm{~cm}^{-1}$ spectral region is $\sim 0.5 \mathrm{~mJ}$. The Burleigh WA-4500 wavemeter measured the OPO radiation frequency providing an absolute accuracy better than $1 \mathrm{~cm}^{-1}$ for the pumping radiation. Whenever necessary, the IR absorption spectra were collected during pumping to compensate for the cis to trans tunneling decay. In the latter case, the pumping beam was quasi-collinear with the spectrometer beam, and an interference filter transmitting in the $3300-1100 \mathrm{~cm}^{-1}$ region was attached to the detector to prevent its exposure to the pumping radiation.

The ab initio calculations were performed using the Gaussian 98 package of programs. ${ }^{29}$ The structural, energetic, and vibrational properties of the propionic acid conformers were studied at the MP2/6-311++G(2d,2p) level of approximation, ${ }^{30}$ which is a higher level than the one used in previous studies. ${ }^{17-19}$ The 1D and 2D potential energy curves connecting the conformers of propionic acid were calculated at the same level of theory. The calculated frequencies have been rescaled with correction factors of 0.94 and 0.97 for bands observed above and below $2000 \mathrm{~cm}^{-1}$, respectively. The scaling factors are used following Radom and Scott. ${ }^{31}$ Transformation of the ab initio Cartesian harmonic force constants to the molecule-fixed internal coordinates system allowed for the ordinary normal coordinate analysis as described by Schachtschneider. ${ }^{32}$ This procedure evaluates the potential energy distribution (PED) associated with each normal vibrational mode under the harmonic assumption. The symmetry coordinates used to perform the normal coordinate analysis are defined in Table S1 provided as Supporting Information (SI).

\section{Results}

1. Computational Results. In agreement with previous theoretical predictions, ${ }^{17-19}$ the present ab initio calculations give four nonequivalent minima on the PES of propionic acid. The geometries of the four conformers, their relative energies, and the barriers to internal rotation around the $\mathrm{C}-\mathrm{O}$ and $\mathrm{C}_{\alpha}-\mathrm{C}$ bonds are shown in Figure 1. The potential energy profiles for conformational interconversion are shown in Figure 2. Only one possible arrangement around the $\mathrm{C}_{\alpha}-\mathrm{C}_{\beta}$ bond is stable, which minimizes steric repulsion between the methyl and methylene hydrogen atoms. In the present article, the stable arrangements 


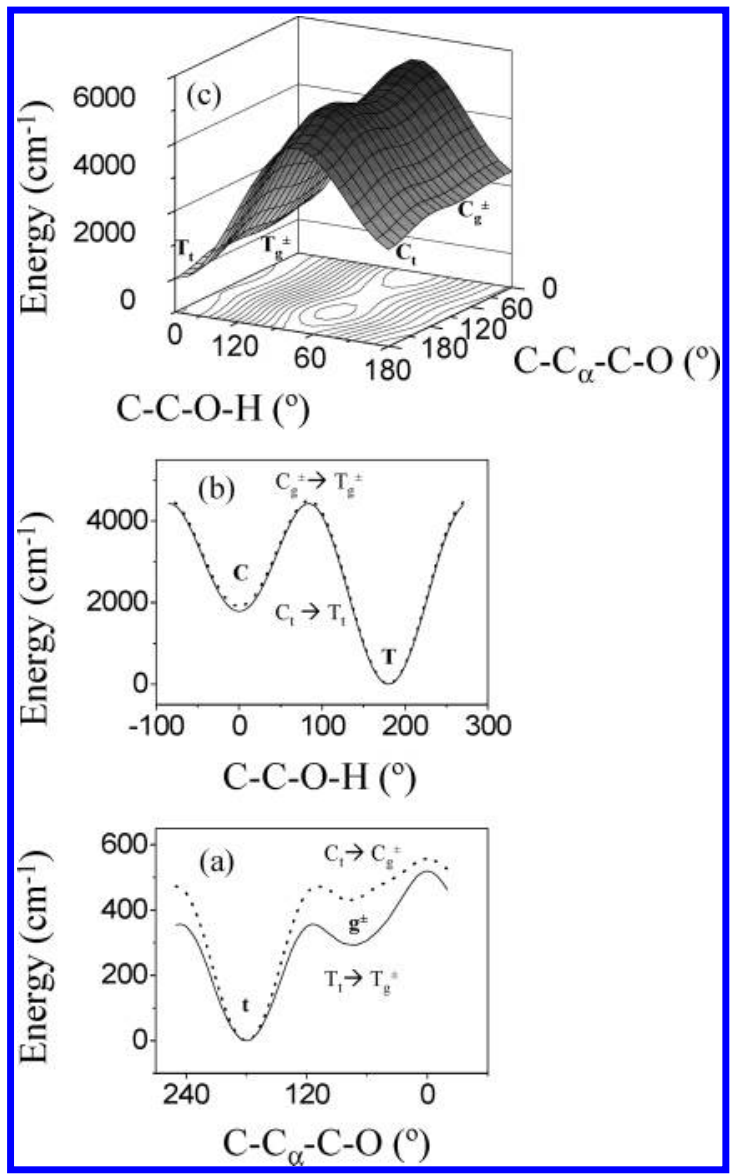

Figure 2. One- and two-dimensional potential energy surfaces (PES) of propionic acid as a function of the $\mathrm{C}_{\alpha}-\mathrm{C}$ and $\mathrm{C}-\mathrm{O}$ torsional coordinates. (a) Rotation along the $\mathrm{C}_{\alpha}-\mathrm{C}$ axis, which corresponds to the $\mathrm{T}_{\mathrm{t}} \leftrightarrow \mathrm{T}_{\mathrm{g}}{ }^{ \pm}$(solid line) and $\mathrm{C}_{\mathrm{t}} \leftrightarrow \mathrm{C}_{\mathrm{g}}{ }^{ \pm}$(dotted line) isomerization reactions. (b) Rotation along the $\mathrm{C}-\mathrm{O}$ axis, which corresponds to the $\mathrm{T}_{\mathrm{t}} \leftrightarrow \mathrm{C}_{\mathrm{t}}$ (solid line) and $\mathrm{T}_{\mathrm{g}}{ }^{ \pm} \leftrightarrow \mathrm{C}_{\mathrm{g}}{ }^{ \pm}$(dotted line) isomerization reactions. (c) Simultaneous rotation along the $\mathrm{C}_{\alpha}-\mathrm{C}$ and $\mathrm{C}-\mathrm{O}$ axes. The lowestenergy minimum is set to zero.

with respect to the $\mathrm{C}-\mathrm{O}$ bond (trans and cis) are denoted by the capital letters $\mathrm{T}$ and $\mathrm{C}$, respectively, and the small letters refer to the arrangements around the $\mathrm{C}_{\alpha}-\mathrm{C}$ bond ( $\mathrm{t}$ for the trans and $\mathrm{g}^{ \pm}$for the two degenerate gauche arrangements).

As generally found for simple carboxylic acids, ${ }^{1,5,28}$ the cis arrangement around the $\mathrm{C}-\mathrm{O}$ bond is higher in energy than the trans configuration by ca. $1800 \mathrm{~cm}^{-1}\left(\Delta E_{\mathrm{C}_{\mathrm{t}}-\mathrm{C}_{\mathrm{t}}} \approx 1730 \mathrm{~cm}^{-1}\right.$ and $\Delta E_{\mathrm{T}_{\mathrm{g}}{ }^{ \pm}-\mathrm{T}_{\mathrm{g}}{ }^{ \pm}} \approx 1860 \mathrm{~cm}^{-1}$, see Figure 1 ), and the isomerization barrier for conversion of the trans to the cis arrangement is ca. $4000 \mathrm{~cm}^{-1}\left(E_{\mathrm{T}_{\mathrm{t}} \rightarrow \mathrm{C}_{\mathrm{t}}} \approx 4020 \mathrm{~cm}^{-1}\right.$ and $E_{\mathrm{T}_{\mathrm{g}}{ }^{ \pm} \rightarrow \mathrm{C}_{\mathrm{g}}} \approx 4090$ $\mathrm{cm}^{-1}$, see Figures 1 and 2). The calculated energy differences between the conformers agree with the earlier computational studies, whereas our $\mathrm{T} \rightarrow \mathrm{C}$ barrier is somewhat lower than the results at a lower level of approximation. ${ }^{18,} 19$

In agreement with known experimental and computational results, ${ }^{14-19}$ the most stable arrangement around the $\mathrm{C}_{\alpha}-\mathrm{C}$ bond corresponds to the trans configuration, whereas the degenerate gauche configurations $(\mathrm{C}-\mathrm{C}-\mathrm{C}-\mathrm{O}$ dihedral angle of approximately $\left.\pm 75^{\circ}\right)$ are somewhat higher in energy than the corresponding trans forms $\left(\Delta E_{\mathrm{T}_{\mathrm{g}}{ }^{ \pm}-\mathrm{T}_{\mathrm{t}}} \approx 340 \mathrm{~cm}^{-1}\right.$ and $\Delta E_{\mathrm{C}_{\mathrm{g}}{ }^{ \pm}-\mathrm{C}_{\mathrm{t}}}$ $\approx 470 \mathrm{~cm}^{-1}$ ). The barrier for internal rotation around the $\mathrm{C}_{\alpha}-\mathrm{C}$ bond was found to be ca. $500 \mathrm{~cm}^{-1}\left(E_{\mathrm{T}_{\mathrm{t}} \rightarrow \mathrm{T}_{\mathrm{g}}} \approx 400 \mathrm{~cm}^{-1}\right.$ and $E_{\mathrm{C}_{\mathrm{t}} \rightarrow \mathrm{C}_{\mathrm{g}}} \approx 560 \mathrm{~cm}^{-1}$ ).

The calculated energy difference between the gauche and trans $\mathrm{C}_{\alpha}-\mathrm{C}$ arrangements in propionic acid is similar to the corresponding values in lipids, saturated hydrocarbons (150- $\left.400 \mathrm{~cm}^{-1}\right),{ }^{33-36}$ and other $\alpha$-substituted carbonyl compounds such as propionyl fluoride, propionyl chloride, and chloroacetic acid. ${ }^{20-23}$ The energy barrier predicted for the trans $\rightarrow$ gauche $\mathrm{C}_{\alpha}-\mathrm{C}$ internal rotation in propionic acid is closer to those found in propionyl fluoride and propionyl chloride $\left(680-820 \mathrm{~cm}^{-1}\right)^{20,21}$ rather than to the average values reported for saturated hydrocarbons $\left(1000-1400 \mathrm{~cm}^{-1}\right) .^{33-36}$

Direct interconversion between the two degenerate gauche configurations of the $\mathrm{C}-\mathrm{C}-\mathrm{C}-\mathrm{O}$ moiety (i.e., the $\mathrm{T}_{\mathrm{g}}{ }^{+} \rightarrow \mathrm{T}_{\mathrm{g}}{ }^{-}$ or $\mathrm{C}_{\mathrm{g}}{ }^{+} \rightarrow \mathrm{C}_{\mathrm{g}}^{-}$process) can also take place (Figure 2). The transition state for these processes corresponds to the syn configuration around the $\mathrm{C}_{\alpha}-\mathrm{C}$ bond. The calculated syn barriers for the $\mathrm{T}_{\mathrm{g}}{ }^{+} \rightarrow \mathrm{T}_{\mathrm{g}}{ }^{-}$and $\mathrm{C}_{\mathrm{g}}{ }^{+} \rightarrow \mathrm{C}_{\mathrm{g}}{ }^{-}$processes are $\sim 180$ and $100 \mathrm{~cm}^{-1}$, respectively. These values are somewhat smaller than those obtained previously at a lower level of theory (240 $\left.\mathrm{cm}^{-1}\right) .{ }^{17}$ The syn barriers found for propionic acid are also lower than the corresponding barriers in propionyl fluoride (258 $\left.\mathrm{cm}^{-1}\right)^{21}$ and propionyl chloride (1230 or $558 \mathrm{~cm}^{-1}$, depending on the method used). ${ }^{20}$

The direct conversion between the conformers differing by internal rotation about both $\mathrm{C}-\mathrm{O}$ and $\mathrm{C}_{\alpha}-\mathrm{C}$ bonds (the $\mathrm{C}_{\mathrm{g}}{ }^{ \pm} / \mathrm{T}_{\mathrm{t}}$ and $\mathrm{C}_{\mathrm{t}} / \mathrm{T}_{\mathrm{g}}{ }^{ \pm}$pairs of conformers, see Figure 1) can be also estimated. The second-order transition state associated with the simultaneous rotation along the two torsional coordinates $\left(\mathrm{C}_{\alpha}-\right.$ $\mathrm{C} / \mathrm{C}-\mathrm{O}$ ) was found in the $2 \mathrm{D}$ potential energy curve at $\sim 4740$ $\mathrm{cm}^{-1}$ above the conformational ground state. Interestingly, in this second-order transition state, the $\mathrm{C}-\mathrm{C}-\mathrm{C}-\mathrm{O}$ and $\mathrm{C}-\mathrm{C}-$ $\mathrm{O}-\mathrm{H}$ dihedral angles agree with the first-order transition states found along each of the torsional coordinates (116 and $83^{\circ}$, respectively).

2. Experimental Results. The $T_{t}$ conformer is the only form present in the as-deposited matrix. For both PA-OH and PA$\mathrm{OD}$, the spectrum of $\mathrm{T}_{\mathrm{t}}$ shows the splitting of bands due to the interaction of the isolated molecule with inhomogeneous local surroundings (matrix site effect). For PA-OH, the absorption bands of the fundamental and first overtone of the hydroxyl stretching mode ( $\nu \mathrm{OH}$ and $2 \nu \mathrm{OH}$, respectively) are shown in Figure 3. Conformational isomerization was induced site selectively by using tunable narrow-band radiation as found for $\mathrm{HONO}^{37}$ and formic acid. ${ }^{2,38}$ The site selectivity upon excitation of the $2 v \mathrm{OH}$ mode of PA-OH is demonstrated in Figure 3, which shows holes burned in the $v \mathrm{OH}$ absorption envelope of $\mathrm{T}_{\mathrm{t}}$ upon pumping at four different frequencies.

When the deposited PA-OH(D)/Ar matrix is irradiated at $\sim 6960 \mathrm{~cm}^{-1}(2 \nu \mathrm{OH})$ or $\sim 5170 \mathrm{~cm}^{-1}(2 \nu \mathrm{OD})$, the bands of the $\mathrm{T}_{\mathrm{t}}$ conformer decrease, and new bands emerge. The lightinduced spectral changes are due to conformational isomerization induced by vibrational excitation of the $T_{t}$ conformer. The emerging bands can be divided into two sets assigned to the $\mathrm{T}_{\mathrm{g}}{ }^{ \pm}$and $\mathrm{C}_{\mathrm{t}}$ forms (see later). The two sets of bands are distinguished by their behavior upon IR pumping and dark decay kinetics at $8-15 \mathrm{~K}$.

In the case of PA-OH, the spectral changes induced by excitation of the $T_{t}$ form are shown in trace a of Figure 4. Trace $\mathrm{b}$ illustrates the changes taking place after several minutes in the dark. One set of light-induced bands quickly decreases ( $k$ $\approx 6 \times 10^{-2} \mathrm{~s}^{-1}$ ) after interrupting the pumping, whereas the other set is much more stable $\left(k \approx 10^{-6} \mathrm{~s}^{-1}\right)$. The quickly decaying bands (marked with dots in Figure 4) originate from the $\mathrm{C}_{\mathrm{t}}$ conformer, and the more stable bands belong to the $\mathrm{T}_{\mathrm{g}}{ }^{ \pm}$ form. In both cases, the decay of the photoproduced conformers regenerates the $T_{t}$ form. Remarkably, the $T_{g}{ }^{ \pm} \rightarrow T_{t}$ recovering process is strongly enhanced at higher temperatures as shown 


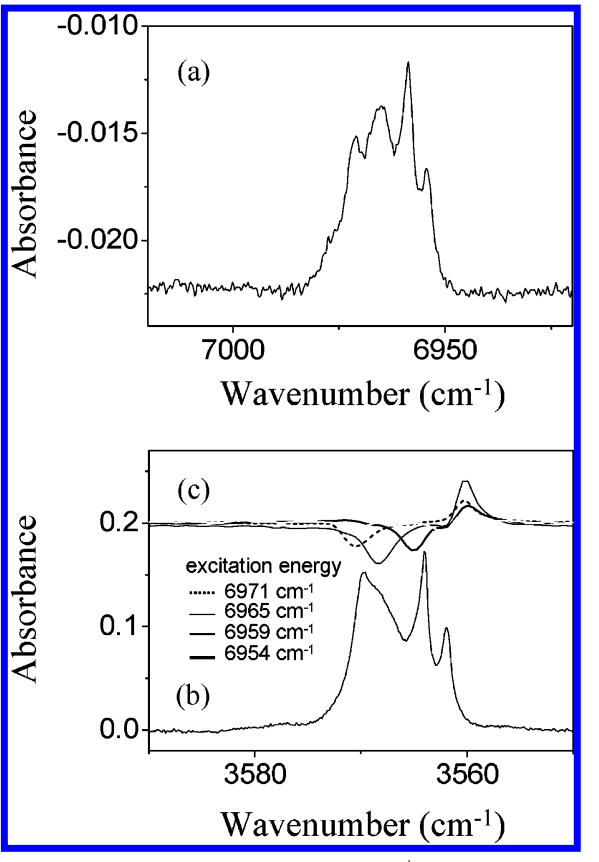

Figure 3. Absorption bands of the $\mathrm{T}_{\mathrm{t}}$ and $\mathrm{T}_{\mathrm{g}}{ }^{ \pm}$conformers of propionic acid in an Ar matrix at $8 \mathrm{~K}$ : (a) $2 \nu \mathrm{OH}\left(\sim 6970 \mathrm{~cm}^{-1}\right)$ mode of $\mathrm{T}_{\mathrm{t}}$, (b) $\nu \mathrm{OH}\left(\sim 3570 \mathrm{~cm}^{-1}\right)$ mode of $\mathrm{T}_{\mathrm{t}}$, and (c) difference spectra showing the photoinduced changes in the $\nu \mathrm{OH}$ absorption after irradiation of the $2 v \mathrm{OH}$ mode of $\mathrm{T}_{\mathrm{t}}$ at different frequencies where the $\mathrm{T}_{\mathrm{t}}$ bands decrease and the $\mathrm{T}_{\mathrm{g}}{ }^{ \pm}$bands increase.

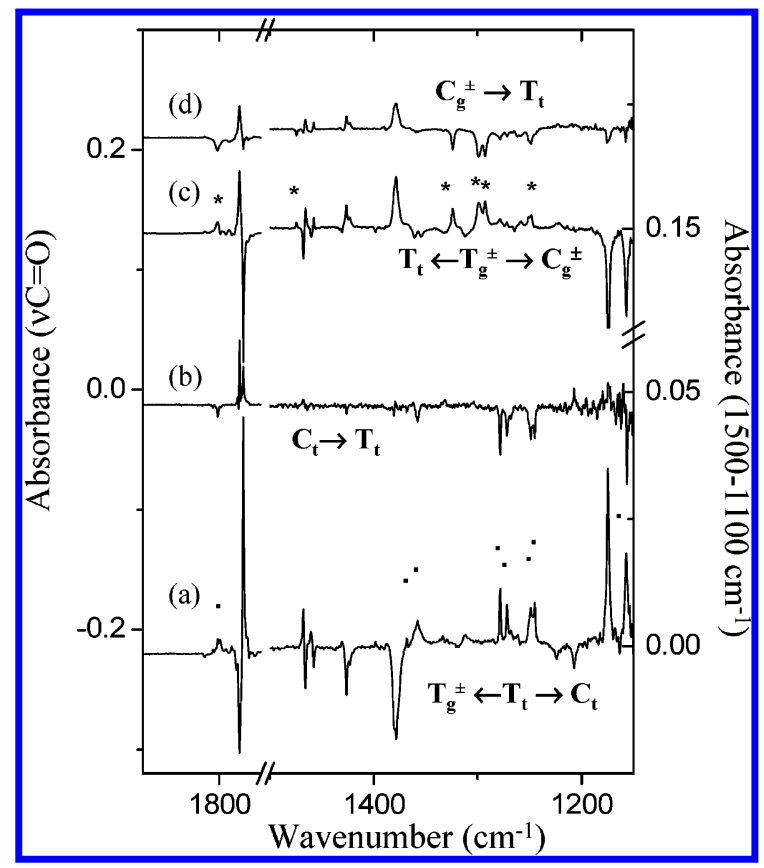

Figure 4. Spectral changes upon excitation of the $2 v \mathrm{OH}$ mode of $\mathrm{T}_{t}$ and $\mathrm{T}_{\mathrm{g}}{ }^{ \pm}$conformers (traces a and $\mathrm{c}$, respectively) and dark decay of the $\mathrm{C}_{\mathrm{t}}(\mathbf{\square})$ and $\mathrm{C}_{\mathrm{g}}{ }^{ \pm}\left({ }^{*}\right)$ conformers (traces $\mathrm{b}$ and $\mathrm{d}$, respectivel). Difference spectra a and c are obtained by subtracting the spectra recorded before pumping from those recorded under pumping. Difference spectra $b$ and $d$ are obtained by subtracting the spectra recorded under pumping from those recorded after a few minutes in the dark.

in Figure 5 (1 order of magnitude variation in the rate constant upon changing between 8 and $12 \mathrm{~K}$ ).

Excitation of the $2 \nu \mathrm{OH}$ mode of the $\mathrm{T}_{\mathrm{g}}{ }^{ \pm}$conformer (at $\sim 6950$ $\mathrm{cm}^{-1}$ ) promotes its conversion back to the $\mathrm{T}_{\mathrm{t}}$ form and its isomerization to a new species identified as the $\mathrm{C}_{\mathrm{g}}{ }^{ \pm}$conformer (see trace $\mathrm{c}$ in Figure 4). The photoinduced $\mathrm{T}_{\mathrm{g}}{ }^{ \pm} \rightarrow \mathrm{T}_{\mathrm{t}}$ conversion is a very efficient process, transferring ca. $70 \%$ of the molecules

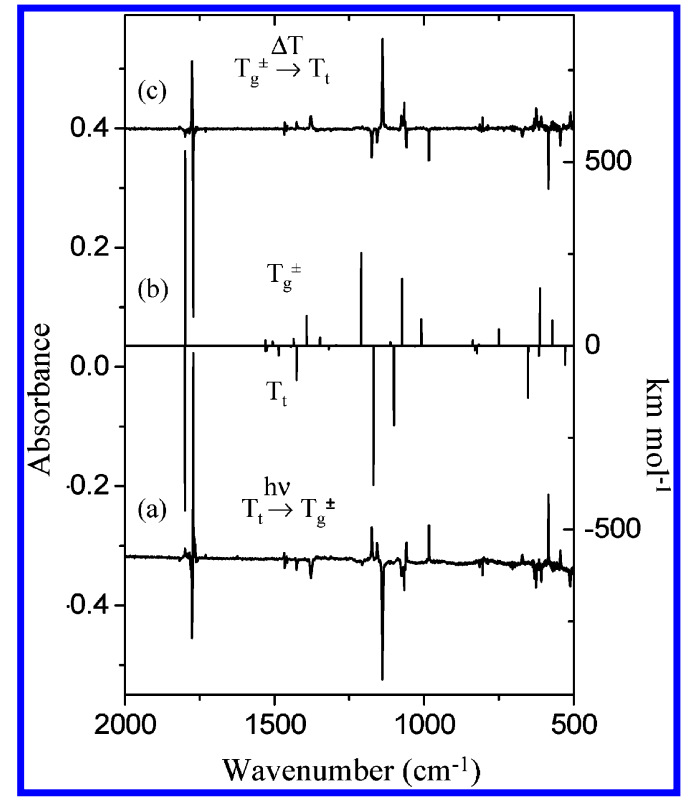

Figure 5. Difference IR absorption spectra for PA-OH showing (a) the effect of excitation of the $2 \nu \mathrm{OH}$ mode of the monomer isolated in an Ar matrix, (b) the MP2/6-311G(2d,2p) calculated spectra for the $T_{t}$ (negative bands) and $\mathrm{T}_{\mathrm{g}}{ }^{ \pm}$(positive bands) forms of propionic acid, and (c) the effect of annealing an Ar matrix containing the $\mathrm{T}_{\mathrm{t}}$ and $\mathrm{T}_{\mathrm{g}}{ }^{ \pm}$ conformers at $12 \mathrm{~K}$ for $\sim 20 \mathrm{~min}$.

from the $\mathrm{T}_{\mathrm{g}}{ }^{ \pm}$to the $\mathrm{T}_{\mathrm{t}}$ state in a few minutes of irradiation. The bands of the $\mathrm{C}_{\mathrm{g}}{ }^{+}$conformer (marked with an asterisk in Figure 4) can be observed only during the pumping of $\mathrm{T}_{\mathrm{g}}{ }^{ \pm}$because they quickly decay in the dark. The decrease of the $\mathrm{C}_{\mathrm{g}}{ }^{ \pm}$bands is accompanied with the growth of the $T_{t}$ bands, showing that this conformer decays to the most stable conformer. The fast dark decay of both $\mathrm{C}_{\mathrm{t}}$ and $\mathrm{C}_{\mathrm{g}}{ }^{ \pm}$conformers is due to a phononassisted tunneling process, which has been shown to be common for internal rotation around the $\mathrm{C}-\mathrm{O}$ bond in simple carboxylic acids such as formic and acetic acids. ${ }^{3,7}$

For the deuterated isotopologue (PA-OD), the $\mathrm{C}_{\mathrm{t}}$ and $\mathrm{T}_{\mathrm{g}}{ }^{ \pm}$ conformers produced by excitation of the $\mathrm{T}_{\mathrm{t}}$ form are quite stable at $8 \mathrm{~K}$. In fact, when compared to $\mathrm{PA}-\mathrm{OH}$, the $\mathrm{C}_{\mathrm{t}}$ to $\mathrm{T}_{\mathrm{t}}$ conversion by tunneling slows down by ca. 4 orders of magnitude. Nevertheless, the spectral signatures of the two photoproduced conformers could also be reliably separated for this isotopologue. First, the emerging bands of the two photoproduced conformers grow at different rates when pumping at different frequencies within the $2 \nu \mathrm{OD}$ absorption of the $\mathrm{T}_{t}$ conformer (high-frequency pumping (HF) at $\sim 5175 \mathrm{~cm}^{-1}$ and low-frequency pumping (LF) at $5170 \mathrm{~cm}^{-1}$ ). These results are shown in Figures 6 and 7 (trace a in both Figures) as difference spectra, where the $C_{t}$ and $T_{g}{ }^{ \pm}$bands increase and the $T_{t}$ bands decrease. Second, the two conformers decay at different rates in the dark upon annealing. The $\mathrm{T}_{\mathrm{g}}{ }^{ \pm} \rightarrow \mathrm{T}_{\mathrm{t}}$ isomerization at 15 $\mathrm{K}$ is faster at least by 2 orders of magnitude than the $\mathrm{C}_{\mathrm{t}} \rightarrow \mathrm{T}_{\mathrm{t}}$ process (see trace $\mathrm{c}$ in Figure 7). Finally, it is also possible to selectively excite the $2 \nu \mathrm{OD}$ mode of the $\mathrm{T}_{\mathrm{g}}{ }^{ \pm}$conformer (which appears to be slightly redshifted from the $2 \nu \mathrm{OD}$ absorption of $\mathrm{T}_{\mathrm{t}}$ ). The excitation of $\mathrm{T}_{\mathrm{g}}{ }^{ \pm}$decreases its bands, a new set of bands emerges that can be assigned to the $\mathrm{C}_{\mathrm{g}}{ }^{ \pm}$conformer, and the $\mathrm{T}_{\mathrm{t}}$ form is partially recovered. Without the pumping of $\mathrm{T}_{\mathrm{g}}{ }^{ \pm}$, the $\mathrm{C}_{\mathrm{g}}{ }^{ \pm}$conformer converts to the most stable $\mathrm{T}_{\mathrm{t}}$ conformer. As for the $\mathrm{C}_{\mathrm{t}} \rightarrow \mathrm{T}_{\mathrm{t}}$ tunneling, $\mathrm{C}_{\mathrm{g}}{ }^{ \pm} \rightarrow \mathrm{T}_{\mathrm{t}}$ is much slower in PA-OD than in PA-OH (roughly by 2 orders of magnitude).

Tables 1 and 2 present the observed frequencies for the four conformers of matrix-isolated PA-OH and PA-OD together with 


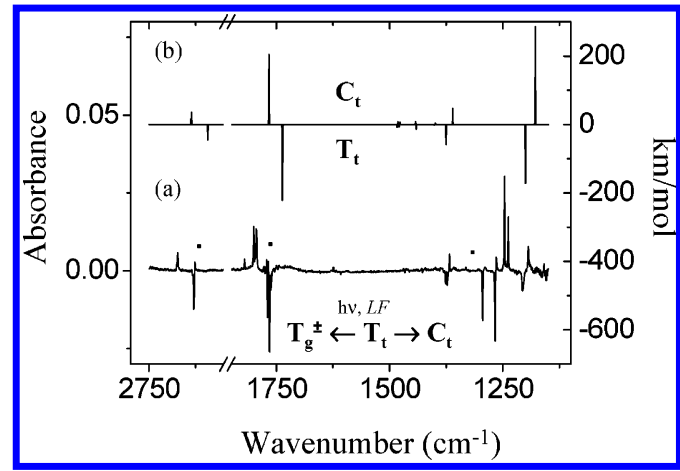

Figure 6. Difference IR absorption spectra for PA-OD showing (a) the result of vibrational excitation of the $T_{t}$ conformer at $5170 \mathrm{~cm}^{-1}$ (LF) and (b) the MP2/6-311++(2d,2p) calculated spectra for the $T_{t}$ (negative bands) and $\mathrm{C}_{\mathrm{t}}$ (positive bands) forms. In plot a, the bands of the $\mathrm{C}_{\mathrm{t}}$ and $\mathrm{T}_{\mathrm{g}}{ }^{ \pm}$(marked with dots) conformers increase, and the $\mathrm{T}_{\mathrm{t}}$ bands decrease.

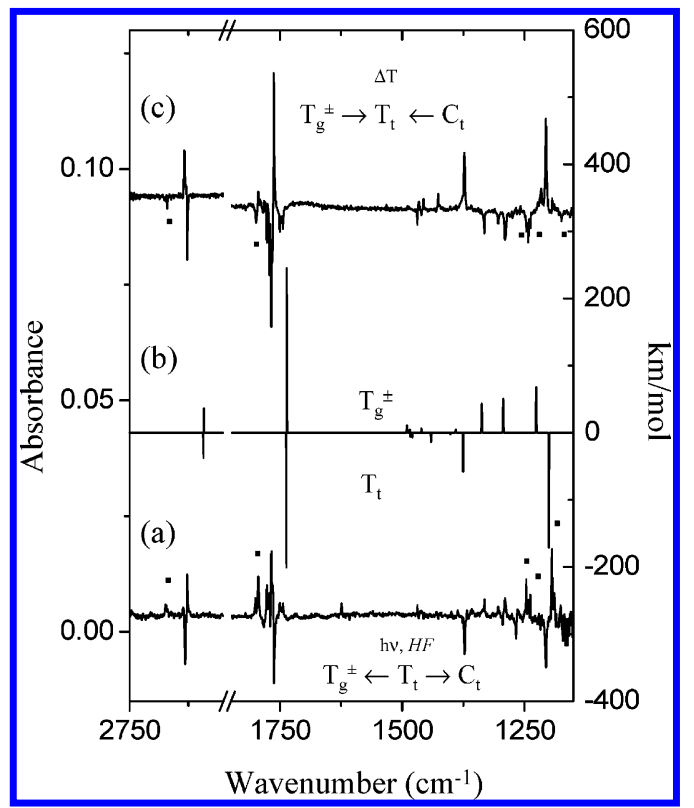

Figure 7. Difference IR absorption spectra for PA-OD showing (a) the result of vibrational excitation of the $T_{t}$ conformer at $5175 \mathrm{~cm}^{-1}$ (HF), (b) the MP2/6-311++(2d,2p) calculated spectra for the $T_{t}$ (negative bands) and $\mathrm{T}_{\mathrm{g}}{ }^{ \pm}$(positive bands) conformer, and (c) the effect of annealing an Ar matrix containing the $\mathrm{T}_{\mathrm{t}}, \mathrm{T}_{\mathrm{g}}{ }^{ \pm}$, and $\mathrm{C}_{\mathrm{t}}$ forms at $15 \mathrm{~K}$ for $\sim 15 \mathrm{~min}$. In plot a, the bands of the $\mathrm{C}_{\mathrm{t}}$ (marked with dots) and $\mathrm{T}_{\mathrm{g}}{ }^{ \pm}$ conformers increase, and the $\mathrm{T}_{\mathrm{t}}$ bands decrease. In plot $\mathrm{c}$, the opposite behavior is observed: the $T_{t}$ bands increase, and the bands of $T_{\mathrm{g}}{ }^{ \pm}$and $\mathrm{C}_{\mathrm{t}}$ (marked with dots) are bleached.

the corresponding calculated [MP2/6-311++G(2d,2p)] frequencies, intensities, and PEDs.

\section{Discussion}

1. Conformational Cooling during Sample Deposition. Taking into consideration the calculated relative energies of the four conformers of propionic acid, the populations of the $T_{t}$ and $\mathrm{T}_{\mathrm{g}}{ }^{ \pm}$conformers are expected to be approximately 73 and $27 \%$ at room temperature (accounting for the degeneracy of the $\mathrm{T}_{\mathrm{g}}$ forms), whereas those of the $\mathrm{C}_{\mathrm{t}}$ and $\mathrm{C}_{\mathrm{g}}{ }^{ \pm}$should be below $1 \%$. Note that at $488 \mathrm{~K}$ the estimated populations of the $\mathrm{T}_{\mathrm{t}}$ and $\mathrm{T}_{\mathrm{g}}{ }^{ \pm}$forms based on their computational relative energies are 58 and $42 \%$, in good agreement with the experimentally estimated populations of propionic acid conformers with planar and nonplanar heavy-atom skeletons (ca. 50 and 40\%, respectively). ${ }^{14}$ Therefore, if the low-temperature matrix could ef- ficiently freeze the equilibrium population of the deposited gaseous conformational mixture, it should have been possible to detect the presence of both $\mathrm{T}_{\mathrm{t}}$ and $\mathrm{T}_{\mathrm{g}}{ }^{ \pm}$forms in the deposited matrix. However, for both PA-OH and PA-OD, only one conformer was found to be present in the deposited matrixes, whose spectral signature closely matches that predicted for the most stable $\mathrm{T}_{\mathrm{t}}$ conformer (Figures 5 and 6 and Tables 1 and 2). The absence of the $\mathrm{T}_{\mathrm{g}}{ }^{ \pm}$conformer can be attributed to its fast conversion to the lowest-energy conformer during deposition at $15 \mathrm{~K}$. This conformational cooling is commonly associated with low isomerization barriers $\left(<400 \mathrm{~cm}^{-1}\right) .{ }^{39,40}$ Indeed, the computational barrier for the $\mathrm{T}_{\mathrm{g}}^{ \pm} \rightarrow \mathrm{T}_{\mathrm{t}}$ isomerization is $\sim 60$ $\mathrm{cm}^{-1}$, which supports the fact that the $\mathrm{T}_{\mathrm{g}}{ }^{ \pm}$form, presumably present in the gaseous mixture, can easily decay to the ground conformational state. In agreement with this interpretation, we observed the decay of the photoproduced $\mathrm{T}_{\mathrm{g}}{ }^{ \pm}$conformer back to $\mathrm{T}_{\mathrm{t}}$ by an over-barrier process with a strong temperature dependence, which is consistent with the calculated $\mathrm{T}_{\mathrm{g}}{ }^{ \pm} \rightarrow \mathrm{T}_{\mathrm{t}}$ isomerization barrier.

2. Assignment of the Spectra of PA-OH. The spectra of the $\mathrm{T}_{\mathrm{t}}$ and $\mathrm{T}_{\mathrm{g}}{ }^{ \pm}$conformers are compared in Figure 5. The difference spectrum shown by trace a was obtained by subtracting the spectrum of the deposited matrix from the spectrum recorded after several minutes of irradiation of $T_{t}$ and $1 \mathrm{~min}$ in the dark. The dark period leads to a decay of the $C_{t}$ conformer to the $\mathrm{T}_{\mathrm{t}}$ form, hence this spectrum shows only the result of the $\mathrm{T}_{\mathrm{t}} \rightarrow \mathrm{T}_{\mathrm{g}}{ }^{ \pm}$photoprocess. A comparison of trace a with the calculated spectra of $\mathrm{T}_{\mathrm{t}}$ and $\mathrm{T}_{\mathrm{g}}{ }^{ \pm}$shown in trace $\mathrm{b}$ demonstrates good general agreement between the experiment and theory. This agreement makes the assignment of the spectrum of both the $T_{t}$ form present in the deposited matrix and the photoproduced $\mathrm{T}_{\mathrm{g}}{ }^{ \pm}$form straightforward. However, two discrepancies between the calculated and experimental spectra of $\mathrm{T}_{\mathrm{g}}{ }^{ \pm}$can be noticed. First, none of the four bands of $\mathrm{T}_{\mathrm{g}}{ }^{ \pm}$predicted to appear in the $1400-1200 \mathrm{~cm}^{-1}$ region are clearly observed experimentally, and the absence of the medium-intensity $v \mathrm{C}-\mathrm{O}$ band predicted at $1350 \mathrm{~cm}^{-1}$ is especially remarkable. Second, the high-intensity band predicted at $1174 \mathrm{~cm}^{-1}(\delta \mathrm{COH})$ appears as a doublet at 1174 and $1157 \mathrm{~cm}^{-1}$. The first discrepancy is probably due to the computational overestimation of the band intensities and/or to the broadening of the experimental bands in this spectral region, which makes them difficult to discriminate from the background. Indeed, four broad weak bands are seen in the $1400-1200 \mathrm{~cm}^{-1}$ region that can correspond to the apparently missing $\mathrm{T}_{\mathrm{g}}^{ \pm}$vibrations (Table 1). However, it is highly probable that the observed doublet at $1174 / 1157 \mathrm{~cm}^{-1}$ is due to a Fermi resonance between $\delta \mathrm{COH}$ and the first overtone of the $\mathrm{C}-\mathrm{O}$ torsion whose fundamental is observed at $584 \mathrm{~cm}^{-1}$. Similar splitting of the $v \mathrm{C}-\mathrm{O}$ or $\delta \mathrm{COH}$ bands due to Fermi resonance was reported for formic and acetic acids. ${ }^{6,38}$

In the $3300-1100 \mathrm{~cm}^{-1}$ spectral window available for observation of the $\mathrm{C}_{\mathrm{t}}$ conformer, the bands assigned to this form are observed at $\sim 1800 \mathrm{~cm}^{-1}(\nu \mathrm{C}=\mathrm{O}), \sim 1360 \mathrm{~cm}^{-1}\left(\omega \mathrm{CH}_{2}\right)$, and $\sim 1156 \mathrm{~cm}^{-1}(\nu \mathrm{C}-\mathrm{O})$, in good agreement with the computational values of 1773,1361 , and $1134 \mathrm{~cm}^{-1}$, respectively (Figure 4). In addition, two doublets are observed at $\sim 1276$ and $\sim 1248 \mathrm{~cm}^{-1}$, which are ascribed to $\delta \mathrm{COH}$, predicted at $1254 \mathrm{~cm}^{-1}$. The fine structure observed for the $v \mathrm{C}=\mathrm{O}$ and $\omega \mathrm{CH}_{2}$ vibrations of $\mathrm{C}_{\mathrm{t}}$, as well as for the bands ascribed to $\delta \mathrm{COH}$ (Table 1) is presumably due to matrix site effects. However, the large splitting between the two $\delta \mathrm{COH}$ doublets $\left(\sim 30 \mathrm{~cm}^{-1}\right)$ might have a different origin. A possible explanation for this observation is a Fermi interaction with the $\gamma \mathrm{CH}_{2}$ 
TABLE 1: Experimental ${ }^{a}$ and Calculated $[\mathrm{MP} 2 / 6-311++(2 \mathrm{~d}, 2 \mathrm{p})]^{b}$ Frequencies for the Four Conformers of the $\mathrm{CH}_{3} \mathrm{CH}_{2} \mathrm{COOH}$ Monomer

\begin{tabular}{|c|c|c|c|c|c|c|c|c|c|c|c|c|c|c|c|}
\hline \multirow{2}{*}{$\begin{array}{l}\text { assignment } \\
\left(^{\mathrm{PED})^{c}}\right.\end{array}$} & \multicolumn{3}{|c|}{$\mathrm{T}_{\mathrm{t}}$} & \multirow{2}{*}{$\begin{array}{l}\text { assignment } \\
(\mathrm{PED})^{c}\end{array}$} & \multicolumn{3}{|c|}{$\mathrm{T}_{\mathrm{g}}{ }^{\mathrm{N}}$} & \multirow{2}{*}{$\begin{array}{l}\text { assignment } \\
(\mathrm{PED})^{c}\end{array}$} & \multicolumn{3}{|c|}{$\mathrm{C}_{\mathrm{t}}$} & \multirow{2}{*}{$\begin{array}{c}\text { assignment } \\
(\mathrm{PED})^{c}\end{array}$} & \multicolumn{3}{|c|}{$\mathrm{C}_{\mathrm{g}}{ }^{ \pm}$} \\
\hline & $v_{\text {exptl }}$ & $v_{\text {calcd }}$ & $\overline{I_{\text {calcd }}}$ & & $v_{\text {exptl }}$ & $v_{\text {calcd }}$ & $\overline{I_{\text {calcd }}}$ & & $v_{\text {exptl }}$ & $v_{\text {calcd }}$ & $I_{\text {calcd }}$ & & $v_{\text {exptl }}$ & $v_{\text {calcd }}$ & $I_{\mathrm{cal}}$ \\
\hline$\nu \mathrm{OH}(98)$ & $\begin{array}{l}3568.7 \\
3565.0\end{array}$ & 3564.6 & 23 & $\nu \mathrm{OH}(98)$ & 3560.2 & 3563.1 & 23 & $\nu \mathrm{OH}(99)$ & & 3622.6 & 18 & $\nu \mathrm{OH}(99)$ & & 3624.5 & 16 \\
\hline$v \mathrm{HCH}_{2} \mathrm{a} .(95)$ & 3000.6 & 3003.0 & 4 & $\begin{array}{l}\nu \mathrm{CH}_{2}^{\prime}(52)+ \\
v \mathrm{HCH}_{2}^{\prime}(38)\end{array}$ & 3007.4 & 3008.6 & 4 & $v \mathrm{HCH}_{2} \mathrm{a} .(98)$ & & 3007.3 & 4 & $\begin{array}{l}v \mathrm{CH}_{2}^{\prime}(50)+ \\
v \mathrm{HCH}_{2}^{\prime}(37)\end{array}$ & & 3000.4 & \\
\hline$v \mathrm{HCH}_{2} \mathrm{~s} .(100)$ & 2996.3 & 2999.4 & 4 & $v \mathrm{HCH}_{2}(84)$ & 2989.8 & 2996.2 & 3 & $v \mathrm{HCH}_{2} \mathrm{~s} .(100)$ & & 3001.0 & 4 & $v \mathrm{HCH}_{2}(85)$ & & 2996.6 & 4 \\
\hline$v \mathrm{CH}_{2} \mathrm{a} .(94)$ & 2957.1 & 2959.8 & & $\begin{array}{l}v \mathrm{HCH}_{2}^{\prime}(60)+ \\
\left.v \mathrm{CH}_{2} 26\right)\end{array}$ & 2973.3 & 2988.2 & 2 & $v \mathrm{CH}_{2} \mathrm{a} .(97)$ & & 2940.3 & 1 & $\begin{array}{l}v \mathrm{HCH}_{2}^{\prime}(61)+ \\
v \mathrm{CH}_{2}^{\prime}(22)\end{array}$ & & 2980.4 & 2 \\
\hline$v \mathrm{CH}_{2}$ s.(100) & 2952.4 & 2920.0 & 3 & $\left.v \mathrm{CH}_{2(} 94\right)$ & & 2937.0 & 2 & $v \mathrm{CH}_{3}(100)$ & & 2920.4 & 4 & $\nu \mathrm{CH}_{2}(83)$ & & 2915.5 & 4 \\
\hline$v \mathrm{CH}_{3}(100)$ & 2938.1 & 2918.8 & 4 & $\left.v \mathrm{CH}_{3(} 100\right)$ & $\begin{array}{l}2894.0 \\
1798.6\end{array}$ & 2912.7 & 5 & $\nu \mathrm{CH}_{2} \mathrm{~s} .(100)$ & 1807.3 & 2898.1 & 4 & $v \mathrm{CH}_{3}(99)$ & & 2909.4 & 4 \\
\hline & 1817.0 & & & & 1791.7 & & & & 1804.1 & & & & & & \\
\hline$\nu \mathrm{C}=\mathrm{O}(81)$ & 1776.0 & 1745.3 & 74 & $v \mathrm{C}=\mathrm{O}(80)$ & 1784.6 & 1744.5 & 85 & $v \mathrm{C}=\mathrm{O}(83)$ & 1801.4 & 1773.4 & 61 & & & & \\
\hline & 1774.7 & & & & 1771.3 & & & & 1798.2 & & & $v \mathrm{C}=\mathrm{O}(82)$ & 1802.1 & 1769.6 & 72 \\
\hline$\delta \mathrm{HCH}_{2} \mathrm{~s} .(87)$ & 1466.2 & 1483.5 & 3 & $\delta \mathrm{HCH}_{2}(84)$ & 1467.5 & 1490.3 & 3 & $\delta \mathrm{HCH}_{2}$ s.(88) & & 1481.6 & 2 & $\begin{array}{l}\delta \mathrm{HCH}_{2}(55)+ \\
\delta \mathrm{HCH}_{2}^{\prime}(29)\end{array}$ & 1474.4 & 1488.5 & 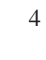 \\
\hline$\delta \mathrm{HCH}_{2} \mathrm{a} .(90)$ & 1457.9 & 1479.2 & 2 & $\delta \mathrm{HCH}_{2}{ }^{\prime}(89)$ & 1458.8 & 1484.1 & 2 & $\delta \mathrm{HCH}_{2} \mathrm{a} .(89)$ & & 1477.4 & 2 & $\begin{array}{l}\delta \mathrm{HCH}_{2}^{\prime}(59)+ \\
\delta \mathrm{HCH}_{2}(19)\end{array}$ & & 1483.2 & \\
\hline$\delta \mathrm{CH}_{2}(97)$ & $\begin{array}{l}1426.6 \\
1423.2\end{array}$ & 1441.2 & 4 & $\delta \mathrm{CH}_{2}(91)$ & 1430 & 1460.9 & 2 & $\delta \mathrm{CH}_{2}(98)$ & & 1443.1 & 3 & $\begin{array}{l}\delta \mathrm{CH}_{2}(80) \\
\delta \mathrm{CH}_{3}(100)\end{array}$ & & $\begin{array}{l}1466.2 \\
1396.5\end{array}$ & 1 \\
\hline$\delta \mathrm{CH}_{3}(89)$ & 1380.9 & 1445.3 & & $\delta \mathrm{CH}_{3}(98)$ & 1360.9 & 1391.6 & 2 & $\delta \mathrm{CH}_{3}(99)$ & & 1399.4 & 1 & $\omega \mathrm{CH}_{2}(65)$ & 1323.9 & 1328.0 & 21 \\
\hline$\omega \mathrm{CH}_{2}(46)$ & 1377.8 & 1383.1 & 17 & $\begin{array}{l}v \mathrm{C}-\mathrm{O}(14)+ \\
\omega \mathrm{CH}_{2(31)}\end{array}$ & 1354.3 & 1350.5 & 13 & $\omega \mathrm{CH}_{2}(68)$ & $\begin{array}{l}1368.1 \\
1357.6\end{array}$ & 1361.3 & 20 & twCH $\mathrm{CH}_{2}(43)$ & $\begin{array}{l}1298.8 \\
1292.7\end{array}$ & 1283.4 & 39 \\
\hline $\begin{array}{l}\delta \mathrm{COH}(44)+ \\
\omega \mathrm{CH}_{2}(24)\end{array}$ & 1224.4 & 1278.9 & 2 & $\omega \mathrm{CH}_{2}(51)$ & 1332.6 & 1307.1 & 4 & $\mathrm{twCH}_{2}(74)$ & & 1274.0 & & $\begin{array}{l}\delta \mathrm{COH}(45) \\
\operatorname{twCH}_{2}(24)\end{array}+$ & $\begin{array}{l}1250.9 \\
1248.7\end{array}$ & 1246.6 & 48 \\
\hline $\begin{array}{l}\operatorname{twCH}_{2}(74)+ \\
\gamma \mathrm{CH}_{3}(19)\end{array}$ & 1207.5 & 1265.8 & & $\mathrm{twCH}_{2}(48)$ & 1310.7 & 1254.4 & & $\begin{array}{l}\delta \mathrm{COH}(71) \\
\gamma \mathrm{CH}_{2}+\delta \mathrm{C}-\mathrm{O}\end{array}$ & $\begin{array}{l}\mathrm{FR} 1278.4 \\
1271.7 \\
\mathrm{FR} 1250.5\end{array}$ & 1254.4 & 100 & $\begin{array}{l}\gamma \mathrm{CH}_{3}(18)+ \\
\delta \mathrm{COH}(24)+ \\
\nu \mathrm{C}-\mathrm{O}(18)+ \\
\gamma \mathrm{CH}_{2}(19)\end{array}$ & & 1174.7 & \\
\hline $\begin{array}{l}\nu \mathrm{C}-\mathrm{O}(25)+ \\
\delta \mathrm{COH}(24)\end{array}$ & 1138.6 & 1134.7 & 62 & $\begin{array}{l}\delta \mathrm{COH}(48) \\
2 \delta \mathrm{CO}\end{array}$ & $\begin{array}{l}\text { FR } 1174.3 \\
\text { FR } 1157.1\end{array}$ & 1173.7 & 40 & $v \mathrm{C}-\mathrm{O}(34)$ & $\begin{array}{l}1246.0 \\
1156.2\end{array}$ & 1133.7 & 11 & $\omega \mathrm{CH}_{3}(42)$ & & 1074.1 & 1 \\
\hline $\begin{array}{l}\gamma \mathrm{CH}_{3}(37)+ \\
\gamma \mathrm{CH}_{2}(31)\end{array}$ & 1075.8 & 1092.9 & & $\omega \mathrm{CH}_{3}(40)$ & & 1079.0 & 2 & $\begin{array}{l}\gamma \mathrm{CH}_{3}(37)+ \\
\gamma \mathrm{CH}_{2}(30)\end{array}$ & & 1087.9 & & $\begin{array}{l}\gamma \mathrm{CH}_{3}(12)+ \\
\nu \mathrm{C}-\mathrm{CH}_{3}(22)+ \\
\text { twCH } \\
\nu \mathrm{C}-\mathrm{O}(15)+\end{array}$ & & 1038.5 & 6 \\
\hline $\begin{array}{l}\omega \mathrm{CH}_{3}(24)+ \\
\nu \mathrm{C}-\mathrm{CH}_{3}(32)\end{array}$ & $\begin{array}{l}1066.7 \\
1066.6\end{array}$ & 1067.7 & 36 & $\begin{array}{l}\gamma \mathrm{CH}_{3}(13)+ \\
\nu \mathrm{C}-\mathrm{C}=\mathrm{O}(22)+ \\
\tau \omega \mathrm{CH}_{2}(13)+ \\
\nu \mathrm{C}-\mathrm{O}(14)\end{array}$ & 1059.1 & 1041.7 & 33 & $\begin{array}{l}\omega \mathrm{CH}_{3}(23)+ \\
\nu \mathrm{C}-\mathrm{CH}_{3}(32)+ \\
\nu \mathrm{C}-\mathrm{O}(23)\end{array}$ & & 1069.0 & 6 & & & & \\
\hline $\begin{array}{l}\nu \mathrm{C}-\mathrm{CH}_{3}(44)+ \\
\omega \mathrm{CH}_{3}(23)\end{array}$ & & 999.6 & & $\nu \mathrm{C}-\mathrm{CH}_{3}(58)$ & 984.0 & 978.9 & 12 & $\begin{array}{l}\nu \mathrm{C}-\mathrm{CH}_{3}(46)+ \\
\omega \mathrm{CH}_{3}(25)\end{array}$ & & 997.2 & 1 & $\nu \mathrm{C}-\mathrm{CH}_{3}(57)$ & & 973.0 & 8 \\
\hline$\nu \mathrm{C}-\mathrm{C}=\mathrm{O}(46)$ & $\begin{array}{l}814.2 \\
812.3\end{array}$ & 805.3 & 2 & $\begin{array}{l}\nu \mathrm{C}-\mathrm{C}=\mathrm{O}(37)+ \\
\nu \mathrm{C}-\mathrm{O}(21)\end{array}$ & $\begin{array}{l}814.4 \\
807.9\end{array}$ & 812.4 & 2 & $\begin{array}{l}\nu \mathrm{C}-\mathrm{C}=\mathrm{O}(41)+ \\
\nu \mathrm{C}-\mathrm{O}(21)\end{array}$ & & 808.4 & 8 & $\begin{array}{l}\nu \mathrm{C}-\mathrm{C}=\mathrm{O}(34)+ \\
v \mathrm{C}-\mathrm{O}(22)\end{array}$ & & 810.1 & 8 \\
\hline $\begin{array}{l}\gamma \mathrm{CH}_{2}(33)+ \\
\gamma \mathrm{CH}_{3}(33)\end{array}$ & 804.6 & 798.6 & 3 & $\begin{array}{l}\gamma \mathrm{CH}_{2}(42)+ \\
\gamma \mathrm{CH}_{3}(33)\end{array}$ & 800.3 & 791.9 & & $\begin{array}{l}\gamma \mathrm{CH}_{2}(35)+ \\
\gamma \mathrm{CH}_{3}(34)+ \\
\gamma \mathrm{C}=\mathrm{O}(20)\end{array}$ & & 804.3 & 2 & $\begin{array}{l}\gamma \mathrm{CH}_{2}(44)+ \\
\gamma \mathrm{CH}_{3}(33)\end{array}$ & & 788.6 & \\
\hline$\tau \mathrm{C}-\mathrm{O}(81)$ & 625.6 & 632.3 & 25 & $\gamma \mathrm{C}=\mathrm{O}(45)$ & $\begin{array}{l}671.5 \\
668.6\end{array}$ & 727.2 & 7 & $\tau \mathrm{OCO}(50)$ & & 608.3 & 1 & $\gamma \mathrm{C}=\mathrm{O}(56)$ & & 715.5 & \\
\hline$\delta \mathrm{OCO}(49)$ & 607.9 & 597.6 & 5 & $\delta \mathrm{C}-\mathrm{O}(75)$ & 584.2 & 594.4 & 26 & & & & & & & & \\
\hline$\gamma \mathrm{C}=\mathrm{O}(54)$ & $\begin{array}{l}510.7 \\
502.8\end{array}$ & 512.6 & 8 & $\delta \mathrm{OCO}(60)$ & 544.2 & 553.7 & 11 & $\begin{array}{l}\gamma \mathrm{C}=\mathrm{O}(41)+ \\
\gamma \mathrm{CH}_{2}(28)+ \\
\delta \mathrm{C}-\mathrm{O}(25) \\
\delta \mathrm{CC}=\mathrm{O}(38)\end{array}$ & & $\begin{array}{c}561.9 \\
459.1\end{array}$ & 2 & $\begin{array}{l}\delta \mathrm{OCO}(64)+ \\
\nu \mathrm{C}-\mathrm{C}=\mathrm{O}(24) \\
\delta \mathrm{C}-\mathrm{O}(90)\end{array}$ & & $\begin{array}{c}570.8 \\
466.3\end{array}$ & $\begin{array}{c}2 \\
30\end{array}$ \\
\hline $\begin{array}{l}\delta \mathrm{CC}=\mathrm{O}(36)+ \\
\delta \mathrm{OCO}(23)\end{array}$ & & 456.9 & 6 & $\delta \mathrm{CC}=\mathrm{O}(75)$ & & 427.9 & 1 & $\delta \mathrm{C}-\mathrm{O}(74)$ & & 450.8 & 27 & $\delta \mathrm{CC}=\mathrm{O}(74)$ & & 438.6 & 3 \\
\hline$\delta \mathrm{CCC}(60)$ & & 246.8 & & $\delta \mathrm{CCC}(67)$ & & 238.3 & & $\begin{array}{l}\delta \mathrm{CCC}(62)+ \\
\delta \mathrm{CC}=\mathrm{O}(35)\end{array}$ & & 250.8 & 3 & $\delta \operatorname{CCC}(70)$ & & 238.6 & 2 \\
\hline$\tau \mathrm{C}-\mathrm{CH}_{3}(96)$ & & 217.2 & & $\tau \mathrm{C}-\mathrm{CH}_{3}(89)$ & & 223.1 & & $\tau \mathrm{C}-\mathrm{CH}_{3}(96)$ & & 215.2 & & $\tau \mathrm{C}-\mathrm{CH}_{3}(93)$ & & 218.2 & \\
\hline$\tau \mathrm{C}-\mathrm{C}(95)$ & & 56.7 & & $\tau \mathrm{C}-\mathrm{C}(95)$ & & 33.1 & & $\tau \mathrm{C}-\mathrm{C}(92)$ & & 62.9 & & $\tau \mathrm{C}-\mathrm{C}(92)$ & & 37.3 & \\
\hline
\end{tabular}

${ }^{a}$ Only the bands affected by the NIR excitation experiments are here listed. The majority of the observed vibrational modes exhibit a site splitting of the absorption. ${ }^{b}$ The ab initio harmonic frequencies are rescaled using the 0.94 and 0.97 correction factors for the regions above and below $2000 \mathrm{~cm}^{-1}$, respectively. The calculated intensities were normalized by the intensity of the strongest band $\left(C_{t}\right.$ band at $\left.1254.4 \mathrm{~cm}^{-1}\right) .{ }^{c}$ In general, symmetry coordinates with contributions higher than $15 \%$ to a particular vibrational mode are shown. Symbols: $v$ - stretching; $\delta$ - bending; $\gamma$ - rocking; $\omega$ - wagging; tw - twisting; $\tau$ - torsion; and FR - involved in Fermi resonance. (See details in the text.)

$+\tau \mathrm{C}-\mathrm{O}$ combination mode, whose fundamentals were predicted to appear at ca. 804 and $451 \mathrm{~cm}^{-1}$ (Table 1).

Finally, the $\mathrm{C}_{\mathrm{g}}{ }^{ \pm}$conformer gives rise to the bands observed at $1802(v \mathrm{C}=\mathrm{O}), 1474\left(\delta \mathrm{HCH}_{2}\right), 1323\left(\omega \mathrm{CH}_{2}\right), \sim 1290\left(\mathrm{twCH}_{2}\right.$, doublet), and $\sim 1250 \mathrm{~cm}^{-1}$ ( $\delta \mathrm{COH}$, doublet) (marked with asterisks in trace d of Figure 4). These are the most intense bands predicted by the calculations in this spectral region, and their positions agree with the computational estimations $(\nu \mathrm{C}=$ $\mathrm{O}, 1770 \mathrm{~cm}^{-1} ; \delta \mathrm{HCH}_{2}, 1488 \mathrm{~cm}^{-1} ; \omega \mathrm{CH}_{2}, 1328 \mathrm{~cm}^{-1} ; \mathrm{twCH}_{2}$ $1283 \mathrm{~cm}^{-1}$; and $\delta \mathrm{COH}, 1247 \mathrm{~cm}^{-1}$ ).

3. Assignment of the Spectra of PA-OD. The assignment of the bands of the most stable conformer in the deuterated isotopologue is straightforward because of the generally good agreement between the experimental and calculated spectra for this form. The assignment of the $\mathrm{T}_{\mathrm{g}}{ }^{ \pm}$and $\mathrm{C}_{\mathrm{t}}$ conformers relies to a great extent on the results of the irradiation experiments where the pumping frequency was varied. As already mentioned, two pumping frequencies were used to excite the $T_{t}$ conformer: high-frequency pumping $(\mathrm{HF})$ at $\sim 5175 \mathrm{~cm}^{-1}$ and lowfrequency pumping (LF) at $5170 \mathrm{~cm}^{-1}$ (Figures 6 and 7).

The $v \mathrm{OD}$ and $v \mathrm{C}=\mathrm{O}$ spectral regions are useful for the identification of both the $\mathrm{T}_{\mathrm{g}}{ }^{ \pm}$and $\mathrm{C}_{\mathrm{t}}$ forms. These two modes are sensitive to the conformation of the carboxylic group. The $\nu \mathrm{OD}$ and $\nu \mathrm{C}=\mathrm{O}$ modes of $\mathrm{C}_{\mathrm{t}}$ appear to be blue shifted from the $T_{t}$ bands by 46 and $30 \mathrm{~cm}^{-1}$, respectively (Table 2). The calculations predicted these shifts at 47 and $30 \mathrm{~cm}^{-1}$, in excellent 
TABLE 2: Experimental ${ }^{a}$ and Calculated $[\mathrm{MP2} / 6-311++(2 \mathrm{~d}, 2 \mathrm{p})]^{b}$ Frequencies for the Four Conformers of the $\mathrm{CH}_{3} \mathrm{CH}_{2} \mathrm{COOD}$ Monomer

\begin{tabular}{|c|c|c|c|c|c|c|c|c|c|c|c|c|c|c|c|}
\hline \multirow{2}{*}{$\begin{array}{l}\text { assignment } \\
(\mathrm{PED})^{c}\end{array}$} & \multicolumn{3}{|c|}{$\mathrm{T}_{\mathrm{t}}$} & \multirow{2}{*}{$\begin{array}{l}\text { assignment } \\
\text { (PED) }^{c}\end{array}$} & \multicolumn{3}{|c|}{$\operatorname{Tg}^{ \pm}$} & \multirow{2}{*}{$\begin{array}{l}\text { assignment } \\
\text { (PED) }^{c}\end{array}$} & \multicolumn{3}{|c|}{$\mathrm{C}_{\mathrm{t}}$} & \multirow{2}{*}{$\begin{array}{l}\text { assignment } \\
\left(^{(P E D)}\right)^{c}\end{array}$} & \multicolumn{3}{|c|}{$\mathrm{Cg}^{ \pm}$} \\
\hline & $v_{\text {exptl }}$ & $v_{\text {calcd }}$ & $\overline{I_{\text {calcd }}}$ & & $v_{\text {exptl }}$ & $v_{\text {calcd }}$ & $\overline{I_{\text {calcd }}}$ & & $v_{\text {exptl }}$ & $v_{\text {calcd }}$ & $\overline{I_{\text {calcd }}}$ & & $v_{\text {exptl }}$ & $v_{\text {calcd }}$ & $\overline{I_{\text {calcd }}}$ \\
\hline$v \mathrm{HCH}_{2} \mathrm{a}(95)$ & 3005.6 & 3003.3 & 5 & $\begin{array}{l}v \mathrm{CH}_{2}^{\prime}(52)+ \\
v \mathrm{HCH}_{2}^{\prime}(38)\end{array}$ & 3008.3 & 3008.6 & 5 & $v \mathrm{HCH}_{2} \mathrm{a}(98)$ & & 3007.3 & 4 & $\begin{array}{l}v \mathrm{CH}_{2}^{\prime}(50) \\
+v \mathrm{HCH}_{2}^{\prime}(37)\end{array}$ & & 3000.4 & 4 \\
\hline$v \mathrm{HCH}_{2} \mathrm{~s}(100)$ & 2996.2 & 2999.4 & 5 & $v \mathrm{HCH}_{2}(84)$ & 2989.6 & 2996.2 & 4 & $v \mathrm{HCH}_{2} \mathrm{~s}(100)$ & & 3001.0 & 4 & $v \mathrm{HCH}_{2}(85)$ & & 2996.6 & 4 \\
\hline$v \mathrm{CH}_{2} \mathrm{a}(94)$ & 2956.9 & 2960.1 & & $\begin{array}{l}v \mathrm{HCH}_{2}^{\prime}(60) \\
+v \mathrm{CH}_{2}^{\prime}(26)\end{array}$ & 2972.2 & 2988.2 & 2 & $v \mathrm{CH}_{2} \mathrm{a}(97)$ & & 2940.3 & 2 & $\begin{array}{l}v \mathrm{HCH}_{2}^{\prime}(61) \\
+v \mathrm{CH}_{2}^{\prime}(22)\end{array}$ & & 2980.4 & 2 \\
\hline$v \mathrm{CH}_{2} \mathrm{~s}(100)$ & 2939.9 & 2920.5 & 3 & $v \mathrm{CH}_{2}(94)$ & 2955.3 & 2937.0 & 2 & $v \mathrm{CH}_{3}(100)$ & & 2920.4 & 5 & $v \mathrm{CH}_{2}(83)$ & & 2915.6 & 4 \\
\hline$v \mathrm{CH}_{3}(100)$ & & 2918.9 & 5 & $v \mathrm{CH}_{3}(100)$ & & 2912.7 & 5 & $v \mathrm{CH}_{2} \mathrm{~s}(100)$ & & 2898.1 & 5 & $v \mathrm{CH}_{3}(99)$ & & 2909.4 & 4 \\
\hline$v \mathrm{OD}(99)$ & $\begin{array}{l}2631.3 \\
2630.4 \\
2629.1\end{array}$ & 2592.3 & 16 & $\nu \mathrm{OD}(99)$ & 2627.1 & 2591.7 & 16 & $v \mathrm{OD}(99)$ & $\begin{array}{l}2675.7 \\
2672.9\end{array}$ & 2636.4 & 13 & $v \mathrm{OD}(99)$ & 2669.6 & 2638.6 & 11 \\
\hline$v \mathrm{C}=\mathrm{O}(85)$ & $\begin{array}{l}1769.9 \\
1765.9 \\
1762.4\end{array}$ & 1736.9 & 78 & $\nu \mathrm{C}=\mathrm{O}(84)$ & $\begin{array}{l}1776.7 \\
1771.3 \\
1767.5 \\
1762.4 \\
1749.8 \\
1744.0\end{array}$ & 1735.8 & 90 & $\nu \mathrm{C}=\mathrm{O}(86)$ & $\begin{array}{l}1820.0 \\
1799.8 \\
1794.1\end{array}$ & 1766.4 & 74 & $\begin{array}{l}\delta \mathrm{HCH}_{2}(20) \\
+\delta \mathrm{HCH}_{2}^{\prime}(28)\end{array}$ & $\begin{array}{l}1798.1 \\
1784.2\end{array}$ & 1488.5 & 86 \\
\hline$\delta \mathrm{HCH}_{2} \mathrm{~s}(87)$ & & 1483.5 & 3 & $\delta \mathrm{HCH}_{2}(84)$ & 1468.9 & 1490.2 & 4 & $\delta \mathrm{HCH}_{2} \mathrm{~s}(88)$ & & 1481.6 & 3 & $\delta \mathrm{HCH}_{2}^{\prime}(60)$ & & 1483.2 & 2 \\
\hline$\delta \mathrm{HCH}_{2} \mathrm{a}(90)$ & & 1479.1 & 2 & $\delta \mathrm{HCH}_{2}^{\prime}(90)$ & & 1484.1 & 2 & $\delta \mathrm{HCH}_{2} \mathrm{a}(89)$ & & 1431.7 & 2 & $\delta \mathrm{CH}_{2}(89)$ & & 1466.0 & 1 \\
\hline$\delta \mathrm{CH}_{2}(98)$ & 1466.7 & 1440.8 & 5 & $\delta \mathrm{CH}_{2}(91)$ & & 1460.8 & 2 & $\delta \mathrm{H}_{2}(98)$ & 1428.8 & 1398.2 & 3 & $\delta \mathrm{CH}_{3}(100)$ & & 1396.5 & 1 \\
\hline$\delta \mathrm{CH}_{3}(93)$ & & 1401.6 & 1 & $\delta \mathrm{CH}_{3}(100)$ & 1400.0 & 1390.8 & 2 & $\delta \mathrm{CH}_{3}(99)$ & & 1399.3 & 1 & $\omega \mathrm{CH}_{2}(73)$ & & 1325.5 & 11 \\
\hline$\omega \mathrm{CH}_{2}(58)$ & $\begin{array}{l}1380.1 \\
1376.7 \\
1372.5\end{array}$ & 1375.6 & 21 & $\omega \mathrm{CH}_{2}(60)$ & $\begin{array}{l}1331.5 \\
1303.8\end{array}$ & 1337.4 & 16 & $\omega \mathrm{CH}_{2}(70)$ & 1367.8 & 1360.5 & 16 & $\mathrm{twCH}_{2}(58)$ & & 1278.8 & 20 \\
\hline $\mathrm{twCH}_{2}(74)$ & & 1266.0 & & $\mathrm{twCH}_{2}(47)$ & 1289.6 & 1293.4 & 18 & $\mathrm{twCH}_{2}(74)$ & $\begin{array}{l}1264.4 \\
1260.9\end{array}$ & 1274.0 & & $\begin{array}{l}\nu \mathrm{C}-\mathrm{O}(21) \\
+\gamma \mathrm{CH}_{3}(20)\end{array}$ & $\begin{array}{l}1238.2 \\
1216.1\end{array}$ & 1209.1 & 47 \\
\hline$v \mathrm{C}-\mathrm{O}(41)$ & $\begin{array}{l}1294.6 \\
1267.4 \\
1206.7 \\
1204.4\end{array}$ & 1200.2 & 61 & $\begin{array}{l}\nu \mathrm{C}-\mathrm{O}(17) \\
+\gamma \mathrm{CH}_{3}(21) \\
+\mathrm{twCH}_{2}(18)\end{array}$ & 1242.5 & 1226.1 & 25 & $v \mathrm{C}-\mathrm{O}(40)$ & $\begin{array}{l}1246.4 \\
1238.1 \\
1193.6\end{array}$ & 1178.5 & 100 & $\begin{array}{l}\gamma \mathrm{CH}_{3}(17) \\
+\gamma \mathrm{CH}_{2}(22) \\
+\mathrm{twCH}_{3}(16)\end{array}$ & & 1082.3 & 8 \\
\hline $\begin{array}{l}\gamma \mathrm{CH}_{3}(37) \\
+\gamma \mathrm{CH}_{2}(31)\end{array}$ & & 1092.7 & & $\begin{array}{l}\rho \mathrm{CH}_{3}(24) \\
+\gamma \mathrm{CH}_{2}(21)\end{array}$ & & 1087.8 & 1 & $\begin{array}{l}\omega \mathrm{CH}_{3}(37) \\
+v \mathrm{C}-\mathrm{CH}_{3}(34)\end{array}$ & & 1089.3 & 7 & $\begin{array}{l}\omega \mathrm{CH}_{3}(38) \\
+v \mathrm{C}-\mathrm{CH}_{3}(21)\end{array}$ & & 1062.6 & 17 \\
\hline $\begin{array}{l}\omega \mathrm{CH}_{3}(38) \\
+v \mathrm{C}-\mathrm{CH}_{3}(34)\end{array}$ & & 1090.7 & & $\begin{array}{l}\omega \mathrm{CH}_{3}(43) \\
+v \mathrm{C}-\mathrm{CH}_{3}(22)\end{array}$ & & 1067.4 & 4 & $\begin{array}{l}\gamma \mathrm{CH}_{3}(37) \\
+\gamma \mathrm{CH}_{2}(30)\end{array}$ & & 1087.8 & - & & & & \\
\hline$v \mathrm{C}-\mathrm{CH}_{3}(45)$ & $\begin{array}{l}1012.2 \\
1000.8\end{array}$ & 1006.5 & 11 & $v \mathrm{C}-\mathrm{CH}_{3}(67)$ & & 979.2 & 5 & $\begin{array}{l}v \mathrm{C}-\mathrm{CH}_{3}(51) \\
+\omega \mathrm{CH}_{3}(21)\end{array}$ & & 998.7 & 1 & $v \mathrm{C}-\mathrm{CH}_{3}(68)$ & & 979.3 & 10 \\
\hline$\delta \mathrm{COD}(48)$ & $\begin{array}{c}963.8 \\
956.5\end{array}$ & 964.0 & 25 & $\begin{array}{l}\delta \mathrm{COD}(54) \\
+v \mathrm{C}-\mathrm{O}(26)\end{array}$ & $\begin{array}{c}984.0 \\
978.9\end{array}$ & 962.8 & 38 & $\begin{array}{l}\delta \mathrm{COD}(48) \\
+v \mathrm{C}-\mathrm{O}(22)\end{array}$ & & 9080 & 2 & $\begin{array}{l}\delta \mathrm{COD}(55) \\
+v \mathrm{C}-\mathrm{O}(24)\end{array}$ & & 899.1 & 1 \\
\hline $\begin{array}{l}\gamma \mathrm{CH}_{3}(34) \\
+\gamma \mathrm{CH}_{2}(33)+ \\
\gamma \mathrm{C}=\mathrm{O}(22)\end{array}$ & & 798.1 & 3 & $\begin{array}{l}\gamma \mathrm{CH}_{2}(40) \\
+\gamma \mathrm{CH}_{3}(31)\end{array}$ & & 794.1 & 1 & $\begin{array}{l}\gamma \mathrm{CH}_{2}(35) \\
+\gamma \mathrm{CH}_{3}(34)+ \\
\rho \mathrm{C}=\mathrm{O}(20)\end{array}$ & & 803.7 & 2 & $v \mathrm{C}-\mathrm{C}=\mathrm{O}(39)$ & & 802.6 & 10 \\
\hline$v \mathrm{C}-\mathrm{C}=\mathrm{O}(55)$ & & 763.8 & 2 & $v \mathrm{C}-\mathrm{C}=\mathrm{O}(37)$ & & 778.1 & 1 & $v \mathrm{C}-\mathrm{C}=\mathrm{O}(46)$ & 802.5 & 793.3 & 11 & $\begin{array}{l}\delta \mathrm{CH}_{2}(46) \\
+\gamma \mathrm{CH}_{3}(33)\end{array}$ & & 786.4 & \\
\hline $\begin{array}{l}\gamma \mathrm{C}=\mathrm{O}(38) \\
+\gamma \mathrm{CH}_{2}(28)+ \\
\tau \mathrm{C}-\mathrm{O}(28)\end{array}$ & & 577.2 & 6 & $\gamma \mathrm{C}=\mathrm{O}(47)$ & & 710.9 & 3 & $\delta \mathrm{OCO}(48)$ & & 604.5 & 2 & $\gamma \mathrm{C}=\mathrm{O}(57)$ & & 709.1 & 2 \\
\hline $\begin{array}{l}\delta \mathrm{OCO}(39) \\
+\delta \mathrm{CC}=\mathrm{O}(22)\end{array}$ & & 570.0 & 5 & $\delta \mathrm{OCO}(63)$ & & 526.7 & 12 & $\begin{array}{l}\gamma \mathrm{C}=\mathrm{O}(53) \\
+\gamma \mathrm{CH}_{2}(30)\end{array}$ & & 549.0 & & $\begin{array}{l}\delta \mathrm{OCO}(63) \\
+v \mathrm{C}-\mathrm{C}=\mathrm{O}(21)\end{array}$ & & 558.0 & 2 \\
\hline $\begin{array}{l}\delta \mathrm{OCO}(30) \\
+\delta \mathrm{CC}=\mathrm{O}(29)\end{array}$ & & 444.2 & 8 & $\tau \mathrm{C}-\mathrm{O}(87)$ & & 443.3 & 18 & $\begin{array}{l}\delta \mathrm{CC}=\mathrm{O}(32) \\
+\delta \mathrm{OCO}(23)\end{array}$ & & 438.8 & & $\delta \mathrm{CC}=\mathrm{O}(72)$ & & 427.3 & 1 \\
\hline $\begin{array}{l}\tau \mathrm{C}-\mathrm{O}(72) \\
+\gamma \mathrm{C}=\mathrm{O}(21)\end{array}$ & & 412.8 & 15 & $\delta \mathrm{CC}=\mathrm{O}(69)$ & & 421.8 & 2 & $\tau \mathrm{C}-\mathrm{O}(91)$ & & 342.7 & 16 & $\tau \mathrm{C}-\mathrm{O}(94)$ & & 347.4 & 15 \\
\hline $\begin{array}{l}\delta \mathrm{CCC}(59) \\
+\delta \mathrm{CC}=\mathrm{O}(38)\end{array}$ & & 244.7 & 1 & $\delta \mathrm{CCC}(60)$ & & 233.0 & & $\begin{array}{l}\delta \mathrm{CCC}(60) \\
+\delta \mathrm{CC}=\mathrm{O}(37)\end{array}$ & & 248.5 & 3 & $\delta \mathrm{CCC}(70)$ & & 237.0 & 2 \\
\hline$\tau \mathrm{C}-\mathrm{CH}_{3}(96)$ & & 215.7 & & $\tau \mathrm{C}-\mathrm{CH}_{3}(84)$ & & 222.2 & & $\tau \mathrm{C}-\mathrm{CH}_{3}(96)$ & & 215.2 & & $\tau \mathrm{C}-\mathrm{CH}_{3}(93)$ & & 217.9 & \\
\hline$\tau \mathrm{C}-\mathrm{C}(95)$ & & 55.3 & & $\tau \mathrm{C}-\mathrm{C}(96)$ & & 33.1 & - & $\tau \mathrm{C}-\mathrm{C}(92)$ & & 62.2 & & $\tau \mathrm{C}-\mathrm{C}(92)$ & & 36.6 & 2 \\
\hline
\end{tabular}

${ }^{a}$ Only the bands affected by the NIR excitation experiments are here listed. The majority of the observed vibrational modes exhibit a site splitting of the absorption bands. ${ }^{b}$ The ab initio harmonic frequencies are rescaled using the 0.94 and 0.97 correction factors for the regions above and below $2000 \mathrm{~cm}^{-1}$, respectively. The calculated intensities were normalized by the intensity of the strongest band $\left(\mathrm{C}_{\mathrm{t}}\right.$ band at $\left.1178.5 \mathrm{~cm}^{-1}\right)$. ${ }^{c}$ Symmetry coordinates with contributions higher than $15 \%$ to a particular vibrational mode are shown. Symbols: $v-$ stretching; $\delta$ - bending; $\gamma-$ rocking; $\omega$ - wagging; tw - twisting; and $\tau$ - torsion.

agreement with the experimental results. The observed shifts are also in agreement with the available data for acetic acid, where a change in conformation from the trans to the cis arrangement around the $\mathrm{C}-\mathrm{O}$ bond leads to blue shifts in these modes of 44 and $30 \mathrm{~cm}^{-1}$, respectively. ${ }^{6,38}$ In the case of $\mathrm{T}_{\mathrm{g}}{ }^{+}$, both the $v \mathrm{OD}$ and $\nu \mathrm{C}=\mathrm{O}$ modes were predicted to be shifted from those of $\mathrm{T}_{\mathrm{t}}$ by less than $1 \mathrm{~cm}^{-1}$. Accordingly, the bands assigned to this conformer are observed at 2627 ( $\nu \mathrm{OD})$ and 1780-1760 $\mathrm{cm}^{-1}(\nu \mathrm{C}=\mathrm{O}$, quartet $)$, which are close to the corresponding bands of $\mathrm{T}_{\mathrm{t}}$ observed at 2630/2631 and 1770$1762 \mathrm{~cm}^{-1}$, respectively.

Most of the $\mathrm{T}_{\mathrm{g}}{ }^{ \pm}$and $\mathrm{C}_{\mathrm{t}}$ bands appear to be split because of matrix-site effects. For each conformer, the positions of the emerging bands remain unchanged for the two pumping experiments (HF and LF), as shown in Figures 6 and 7, but their relative intensity changes with the pumping frequency. This is due to the fact that the pumping efficiency of various matrix sites depends on the pumping frequency, as discussed elsewhere. ${ }^{6,38}$ However, very interestingly, the HF excitation of the $2 v \mathrm{OD}$ mode of the $\mathrm{T}_{t}$ conformer more efficiently promotes the $\mathrm{T}_{\mathrm{t}} \rightarrow \mathrm{T}_{\mathrm{g}}{ }^{ \pm}$conversion, whereas the LF excitation promotes the $T_{t} \rightarrow C_{t}$ conversion with a relatively higher efficiency. Although the bands of both photoproduced conformers $\left(\mathrm{T}_{\mathrm{g}}{ }^{ \pm}\right.$and $\left.\mathrm{C}_{\mathrm{t}}\right)$ appear as a result of both $\mathrm{HF}$ and LF excitation, their relative intensities are strongly affected by the excitation frequency. A detailed analysis of the spectral changes induced by the HF or LF excitations allows us to distinguish between the spectroscopic features originating from molecules isolated in various sites. 
For example, there are three $C_{t}$ absorptions in the 1500-1100 $\mathrm{cm}^{-1}$ region affected essentially by the LF excitation (Figure $6)$. These are the band at $1368 \mathrm{~cm}^{-1}\left(\omega \mathrm{CH}_{2}\right.$, predicted to be a medium-intensity band at $1360 \mathrm{~cm}^{-1}$ ), the weak doublet at $\sim 1263 \mathrm{~cm}^{-1}$ (twCH ${ }_{2}$, predicted to be a very weak band at 1274 $\mathrm{cm}^{-1}$ ), and the very strong doublet observed at $\sim 1244 \mathrm{~cm}^{-1}$ $\left(\nu \mathrm{C}-\mathrm{O}\right.$, predicted at $1178 \mathrm{~cm}^{-1}$ to be the most intense band of the spectrum of this conformer). In the same spectral window, the only band of $\mathrm{C}_{\mathrm{t}}$ clearly connected with the HF excitation is the relatively strong band observed at $1194 \mathrm{~cm}^{-1}$, which is assigned to the $v \mathrm{C}-\mathrm{O}$ mode of the site mostly influenced by the HF excitation (Figure 7). The $\mathrm{T}_{\mathrm{t}}$ bands observed at 1380/ 1377 and $1295 / 1267 \mathrm{~cm}^{-1}$ are essentially associated with the sites affected by the LF excitation, which leads mainly to the $T_{t} \rightarrow C_{t}$ conversion (Figure 6). The two observed doublets for $\mathrm{T}_{\mathrm{t}}$ agree reasonably well with the theoretical spectrum where two relatively intense bands are predicted at $1376\left(\omega \mathrm{CH}_{2}\right)$ and $1200 \mathrm{~cm}^{-1}(v \mathrm{C}-\mathrm{O})$ (Table 2). However, the $\mathrm{T}_{\mathrm{t}}$ bands that are more affected by the HF excitation are observed at $1372\left(\omega \mathrm{CH}_{2}\right)$ and $1207 / 1204 \mathrm{~cm}^{-1}(\nu \mathrm{C}-\mathrm{O})$ (Figure 7$)$, which can be correlated with the bands of $\mathrm{T}_{\mathrm{g}}{ }^{ \pm}$observed at $1332 \mathrm{~cm}^{-1}\left(\omega \mathrm{CH}_{2}\right.$ mode, predicted at $\left.1337 \mathrm{~cm}^{-1}\right), 1290 \mathrm{~cm}^{-1}\left(\mathrm{twCH}_{2}\right.$ mode, predicted at $\left.1293 \mathrm{~cm}^{-1}\right)$, and $1242 \mathrm{~cm}^{-1}(\nu \mathrm{C}-\mathrm{O}$, predicted at $1226 \mathrm{~cm}^{-1}$ ).

Another interesting observation is the large splitting (40-90 $\mathrm{cm}^{-1}$ ) between the two $\nu \mathrm{C}-\mathrm{O}$ features responding differently to the HF and LF excitations, which is observed for both $T_{t}$ and $\mathrm{C}_{\mathrm{t}}$ conformers. The bands associated with the LF excitation exhibit a larger blue shift $\left(60-100 \mathrm{~cm}^{-1}\right)$ relative to the ab initio calculated values, whereas those associated with the $\mathrm{HF}$ excitation almost match the calculated values. This observation points to different mode coupling in the two sites, either between $\nu \mathrm{C}-\mathrm{O}$ and other internal modes or between $\nu \mathrm{C}-\mathrm{O}$ and matrix modes, which seem to be more important in the case of the LF-sensitive sites. Similar deviations $\left(30-90 \mathrm{~cm}^{-1}\right)$ between the observed and calculated $\nu \mathrm{C}-\mathrm{O}$ frequencies were previously observed for formic and acetic acids. 6,38

The assignment of the $\mathrm{C}_{\mathrm{g}} \pm$ bands is based on the spectral changes induced by the excitation of $\mathrm{T}_{\mathrm{g}}{ }^{ \pm}$, although the relatively low concentration of the $\mathrm{C}_{\mathrm{g}}{ }^{ \pm}$conformer limits the number of observed bands of this form. As expected from the calculations, the observed bands of $\mathrm{C}_{\mathrm{g}} \pm$ appear to be slightly shifted but clearly distinguishable from those of the $C_{t}$ form (Table 2), and they fit the most intense bands predicted by the calculations ( $\nu \mathrm{OD}$ at $2670, \nu \mathrm{C}=\mathrm{O}$ doublet at $1798 / 1784$, and $\nu \mathrm{C}-\mathrm{O}$ doublet at $1238 / 1216 \mathrm{~cm}^{-1}$ ).

4. Can the $\mathrm{C}-\mathrm{O}$ and $\mathrm{C}_{\alpha}-\mathrm{C}$ Rotations Occur in a Concerted Way? Excitation of the $2 \nu \mathrm{OH}(\mathrm{D})$ mode introduces an energy in the molecule higher than the computed barriers for isomerization along each of the two internal rotation coordinates $\left(\mathrm{C}_{\alpha}-\mathrm{C}\right.$ and $\left.\mathrm{C}-\mathrm{O}\right)$. All stepwise processes are energetically allowed, and for the excitation of $\mathrm{T}_{\mathrm{t}}$ and $\mathrm{T}_{\mathrm{g}}{ }^{ \pm}$, they were experimentally observed as described earlier. The energy barrier associated with the direct $\mathrm{T}_{\mathrm{t}} \rightarrow \mathrm{C}_{\mathrm{g}}{ }^{ \pm}$and $\mathrm{T}_{\mathrm{g}}{ }^{ \pm} \rightarrow \mathrm{C}_{\mathrm{t}}$ processes, via concerted $\mathrm{C}-\mathrm{O} / \mathrm{C}_{\alpha}-\mathrm{C}$ internal rotation, is predicted to be $4300-4800 \mathrm{~cm}^{-1}$ (Figure 1), which is also smaller than the excitation energy. However, no experimental evidence that excitation of the $2 v \mathrm{OH}(\mathrm{D})$ modes of either $\mathrm{T}_{t}$ or $\mathrm{T}_{\mathrm{g}}{ }^{ \pm}$conformers induces the concerted process is obtained. Indeed, for both PA-OH and PA-OD, neither the $\mathrm{C}_{\mathrm{g}}{ }^{ \pm}$conformer upon excitation of the $T_{t}$ form nor the $C_{t}$ conformer upon excitation of the $\mathrm{T}_{\mathrm{g}}{ }^{ \pm}$form is produced.

However, the $\mathrm{C}_{\mathrm{g}}{ }^{ \pm}$to $\mathrm{T}_{\mathrm{t}}$ decay occurs when the NIR irradiation is interrupted (at $8 \mathrm{~K}$, with incident globar radiation below 3300 $\mathrm{cm}^{-1}$ ). It is then, in principle, possible that the direct $\mathrm{C}_{\mathrm{g}}{ }^{ \pm} \rightarrow \mathrm{T}_{\mathrm{t}}$ conversion is taking place via the concerted mechanism. Because the calculated isomerization barrier for the $\mathrm{C}_{\mathrm{g}}{ }^{ \pm} \rightarrow \mathrm{T}_{\mathrm{t}}$ process is $2542 \mathrm{~cm}^{-1}$, the globar radiation below $3300 \mathrm{~cm}^{-1}$ should not play a determinant role in the concerted process. In fact, the only modes with energy above the barrier that can be excited by the globar are the $\mathrm{C}-\mathrm{H}$ stretching modes (predicted within the $3000-2900 \mathrm{~cm}^{-1}$ spectral range), but their cross sections are so small that they are not experimentally observed. Hence, although the concerted mechanism cannot be excluded, a stepwise process for the conversion of $\mathrm{C}_{\mathrm{g}}{ }^{ \pm}$to $\mathrm{T}_{\mathrm{t}}$ seems to be more plausible. The $\mathrm{C}_{\mathrm{g}}{ }^{ \pm}$form can first decay by tunneling to a vibrationally excited $\mathrm{T}_{\mathrm{g}}{ }^{ \pm}$form, and then partial dissipation of the excess vibrational energy into the $\mathrm{C}_{\alpha}-\mathrm{C}$ rotational coordinate, above the $\mathrm{T}_{\mathrm{g}}{ }^{ \pm} \rightarrow \mathrm{T}_{\mathrm{t}}$ isomerization barrier, can lead to the occurrence of this last process. The isotopic effect in the $\mathrm{C}_{\mathrm{g}}{ }^{ \pm}$ $\rightarrow \mathrm{T}_{\mathrm{t}}$ decay rate (slower rate by at least 2 orders of magnitude for PA-OD) supports a conversion mechanism involving tunneling. The proposed stepwise mechanism is consistent with the model for the dark $\mathrm{C} \rightarrow \mathrm{T}$ tunneling decay in formic and acetic acids from the torsional ground state of the cis conformer to a vibrationally excited state of the trans form. ${ }^{3,7}$

\section{Concluding Remarks}

The conformers of propionic acid were studied by means of ab initio calculations, IR absorption spectroscopy, and narrowband NIR excitation in solid Ar. The calculations predicted the existence of four conformers, differing by internal rotation around the $\mathrm{C}_{\alpha}-\mathrm{C}$ and $\mathrm{C}-\mathrm{O}$ bonds. For both PA-OH and PAOD species, internal rotations were induced by excitation of the first overtone of the hydroxyl stretching modes of different conformers, and IR absorption spectroscopy was used to probe the photoinduced conformational changes. The main results of this study can be summarized as follows:

(1) The IR absorption spectra of the four conformers of propionic acid isolated in solid argon are obtained and assigned on the basis of the ab initio calculated spectra (Tables 1 and 2).

(2) Because of conformational cooling, the ground conformational state $\left(\mathrm{T}_{\mathrm{t}}\right)$ is the only form initially present in the deposited argon matrix. The remaining three conformers $\left(\mathrm{T}_{\mathrm{g}}{ }^{+}\right.$, $\mathrm{C}_{\mathrm{t}}$ and $\mathrm{C}_{\mathrm{g}}{ }^{ \pm}$) can be photoproduced by irradiation in the NIR region. Excitation of the $2 \nu \mathrm{OH}(\mathrm{D})$ mode is efficient in promoting the $\mathrm{C}_{\alpha}-\mathrm{C}$ and $\mathrm{C}-\mathrm{O}$ internal rotations leading to the $\mathrm{T}_{\mathrm{t}} \rightarrow$ $\mathrm{T}_{\mathrm{g}}{ }^{ \pm}, \mathrm{T}_{\mathrm{t}} \rightarrow \mathrm{C}_{\mathrm{t}}, \mathrm{T}_{\mathrm{g}}{ }^{ \pm} \rightarrow \mathrm{T}_{\mathrm{t}}$, and $\mathrm{T}_{\mathrm{g}}{ }^{ \pm} \rightarrow \mathrm{C}_{\mathrm{g}}{ }^{ \pm}$isomerization processes. Although energetically allowed, no direct $\mathrm{T}_{\mathrm{t}} \rightarrow \mathrm{C}_{\mathrm{g}}{ }^{ \pm}$or $\mathrm{T}_{\mathrm{g}}{ }^{ \pm} \rightarrow$ $\mathrm{C}_{\mathrm{t}}$ photoisomerization by concerted rotation around the $\mathrm{C}_{\alpha}-\mathrm{C}$ and $\mathrm{C}-\mathrm{O}$ bonds was observed. The comparison of photochemical processes on propionic, acetic, and formic acids can be found elsewhere. ${ }^{41}$

(3) For PA-OH, the $\mathrm{C}_{t}$ and $\mathrm{C}_{\mathrm{g}}{ }^{ \pm}$conformers are short-lived species due to fast $\mathrm{C}_{\mathrm{t}} \rightarrow \mathrm{T}_{\mathrm{t}}$ and $\mathrm{C}_{\mathrm{g}}{ }^{ \pm} \rightarrow \mathrm{T}_{\mathrm{t}}$ conversions in the absence of irradiation. The much slower decay of these two forms in the case of PA-OD (by ca. 2-4 orders of magnitude) proves the crucial role of tunneling in these isomerization processes.

(4) The $2 v \mathrm{OH}(\mathrm{D})$ absorption band is split by the matrix-site effect. For PA-OD, excitation of $T_{t}$ was performed at two different frequencies within the $2 \nu \mathrm{OD}$ absorption band, leading to site-dependent isomerization efficiencies that aid the discrimination between the spectra of the photoproducts $\left(\mathrm{T}_{\mathrm{g}}{ }^{ \pm}\right.$and $\mathrm{C}_{\mathrm{t}}$ ).

(5) The $\mathrm{T}_{\mathrm{g}}{ }^{ \pm} \rightarrow \mathrm{T}_{\mathrm{t}}$ isomerization takes place in the dark with an appreciable rate $\left(k \approx 10^{-6} \mathrm{~s}^{-1}\right)$, even at the lowest working temperature $(8 \mathrm{~K})$. The very low isomerization barrier associated 
with the $\mathrm{T}_{\mathrm{g}}{ }^{ \pm} \rightarrow \mathrm{T}_{\mathrm{t}}$ process (computationally estimated as 60 $\mathrm{cm}^{-1}$ ) suggests that this isomerization could occur over the barrier. The strong temperature dependence of this process experimentally supports a low barrier for the $\mathrm{T}_{\mathrm{g}}{ }^{+} \rightarrow \mathrm{T}_{\mathrm{t}}$ process.

Acknowledgment. We thank The Academy of Finland for financial support and the Finnish IT Center for Science (CSC) for providing the computational facilities. E.M.S.M. and R.F. acknowledge the Portuguese Foundation for Science and Technology (Ph.D. grants SFRH/BD/4863/2001 and POCTI/ QUI/43366/2001) and the Calouste Gulbenkian Foundation.

Supporting Information Available: Definition of the internal symmetry coordinates used in the normal coordinate analysis of propionic acid. This material is available free of charge via the Internet at http://pubs.acs.org.

\section{References and Notes}

(1) Pettersson, M.; Lundell, J.; Khriachtchev, L.; Räsänen, M. J. Am. Chem. Soc. 1997, 119, 11715.

(2) Maçôas, E. M. S.; Khriachtchev, L.; Pettersson, M.; Juselius, J.; Fausto, R.; Räsänen, M. J. Chem. Phvs. 2003, 119, 11765.

(3) Pettersson, M.; Maçôas, E. M. S.; Khriachtchev, L.; Lundell, J.; Fausto, R.; Räsänen, M. J. Chem. Phvs. 2002, 117, 9095.

(4) Khriachtchev, L.; Maçôas, E.; Pettersson, M.; Räsänen M. J. Am. Chem. Soc. 2002, 124, 10994.

(5) Maçôas, E. M. S.; Khriachtchev, L.; Pettersson, M.; Fausto, R.; Räsänen, M. J. Am. Chem. Soc. 2003, 125, 16188 .

(6) Maçôa, E. M. S.; Khriachtchev, L.; Fausto, R.; Räsänen, M. $\underline{J}$. Phvs. Chem. A 2004, 108, 3380.

(7) Maçôs, E. M. S.; Khriachtchev, L.; Pettersson, M.; Fausto, R.; Räsänen, M. J. Chem. Phvs. 2004, 121, 1331.

(8) Goez, M. Angew. Chem. Int. Ed. 2003, 42, 2336.

(9) Cantor, C. R.; Schimmel, P. R. Biophysical Chemistry; W. H. Freeman: New York, 1980.

(10) Huff, J. B.; Askew, B.; Duff, R. J.; Rebek J. J. Am. Chem. Soc. 1988, 110, 5908.

(11) Tadayoni, B. M.; Parris, K.; Rebek J. J. Am. Chem. Soc. 1989, $111,4503$.

(12) Karle, M.; Bockelmann, D.; Schumann, D.; Griesinger, C.; Koert, U. Angew. Chem., Int. Ed. 2003, 42, 4546.

(13) Berkovic, G.; Krongauz, V.; Weiss, V. Chem. Rev. 2000, 100, 1741.

(14) Derissen, J. L. J. Mol. Struct. 1971, 7, 81.

(15) Stiefvater, O. L. J. Chem. Phvs. 1975, 62, 233.

(16) Stiefvater, O. L. J. Chem. Phvs. 1975, 62, 244

(17) Wiberg, K. B. J. Am. Chem. Soc. 1986, 108, 5817.
(18) Teixeira-Dias, J. J. C.; Fausto, R. J. Mol. Struct. 1986, 144, 199.

(19) Lii, J. H. J. Phys. Chem. A 2002, 106, 8667.

(20) Durig, J. R.; Li, Y.; Shen, S. Y.; Durig, D. T. J. Mol. Struct. 1998, $449,131$.

(21) Durig, D. T.; Shen, S. Y.; Li, Y.; Durig, J. R. Spectrochim. Acta. Part $A$ 2004, 60, 1481.

(22) Fausto, R.; Teixeira-Dias, J. J. C.; Gil, F. P. S. C. J. Chem. Soc., Faradav Trans. 1993, 89, 3235.

(23) Derissen, J. L.; Bijen, J. M. J. M. J. Mol. Struct. 1975, 29, 153.

(24) Nieminen, J.; Pettersson, M.; Räsänen, M. J.Phys. Chem. 1993, 97, 10925.

(25) Goddard, J. D.; Yamaguchi, Y.; Schaefer, H. F. J. Chem. Phvs. 1992, 96, 1158

(26) Pettersson, M.; Maçôas, E. M. S.; Khriachtchev, L.; Fausto, R.; Räsänen, M. J. Am. Chem. Soc. 2003, 125, 4058.

(27) Senent, M. L. Mol. Phys. 2001, 99, 1311.

(28) Hocking, W. H. Z. Naturforsch., A 1976, 31, 1113.

(29) Frisch, M. J.; Trucks, G. W.; Schlegel, H. B.; Scuseria, G. E.; Robb,

M. A.; Cheeseman, J. R.; Zakrzewski, V. G.; Montgomery, J. A., Jr.; Stratmann, R. E.; Burant, J. C.; Dapprich, S.; Millam, J. M.; Daniels, A. D.; Kudin, K. N.; Strain, M. C.; Farkas, O.; Tomasi, J.; Barone, V.; Cossi, M.; Cammi, R.; Mennucci, B.; Pomelli, C.; Adamo, C.; Clifford, S.; Ochterski, J.; Petersson, G. A.; Ayala, P. Y.; Cui, Q.; Morokuma, K.; Malick, D. K.; Rabuck, A. D.; Raghavachari, K.; Foresman, J. B.; Cioslowski, J.; Ortiz, J. V.; Stefanov, B. B.; Liu, G.; Liashenko, A.; Piskorz, P.; Komaromi, I.; Gomperts, R.; Martin, R. L.; Fox, D. J.; Keith, T.; Al-Laham, M. A.; Peng, C. Y.; Nanayakkara, A.; Gonzalez, C.; Challacombe, M.; Gill, P. M. W.; Johnson, B. G.; Chen, W.; Wong, M. W.; Andres, J. L.; Head-Gordon, M.; Replogle, E. S.; Pople, J. A. Gaussian 98, revision A.9; Gaussian, Inc.: Pittsburgh, PA, 1998.

(30) Jensen, F. Introduction to Computational Chemistry; John Wiley \& Sons: Ltd.: Chichester, West Sussex, 1999.

(31) Scott, A. P.; Radom, L. J. Phvs. Chem. 1996, 100, 16502.

(32) Schachtschneider, J. H. Technical Report; Shell Development Co.: Emeryville, CA, 1969.

(33) Marsh, D. Cell. Mol. Life Sci. 2003, 60, 1575.

(34) Kanesaka, I.; Snyder, R. G.; Strauss, H. L. J. Chem. Phvs. 1986, 84,395 .

(35) Herrebout, W. A.; Vanderveken, B. J.; Wang, A.; Durig, J. R. J. Phvs. Chem. 1995, 99, 578.

(36) Smith, G. D.; Jaffe, R. L. J. Phvs. Chem. 1996, 100, 18718.

(37) Khriachtchev, L.; Lundell, J.; Isoniemi, E.; Räsänen, M. J. Chem. Phvs. 2000, 113, 4265 .

(38) Maçôas, E. M. S.; Lundell, J.; Pettersson, M.; Khriachtchev, L.; Fausto, R.; Räsänen, M. J. Mol. Spectrosc. 2003, 219, 70

(39) Reva, I. D.; Stepanian, S. G.; Adamowicz, L.; Fausto, R. Chem. Phvs. Lett. 2003, 374, 631

(40) Barnes, A. J. J. Mol. Struct. 1984, 113, 161.

(41) Maçôas, E. M. S.; Khriachtchev, L.; Pettersson, M.; Fausto, R.; Räsänen, M Phvs. Chem. Chem. Phvs. 2005, 7, 743. 